
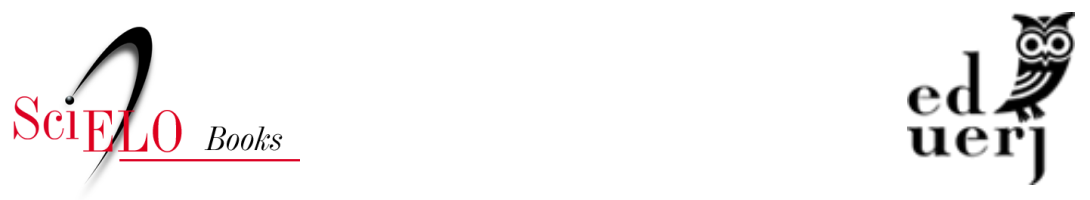

\title{
Capítulo IV - Plantas medicinais: os saberes locais entre os camponeses da comunidade da Fazenda Engenho Novo, São Gonçalo/RJ
}

\author{
Luiz Henrique Marinho Lages \\ Juliana Riane Chagas \\ Marcelo Guerra Santos
}

\section{SciELO Books / SciELO Livros / SciELO Libros}

LAGES, L. H. M., CHAGAS, J. R., and SANTOS, M. G. Plantas medicinais: os saberes locais entre os camponeses da comunidade da Fazenda Engenho Novo, São Gonçalo/RJ. In: SANTOS, M. G., ed. O rural em regiões metropolitanas: a Fazenda Engenho Novo, São Gonçalo [online]. Rio de Janeiro: EDUERJ, 2020, pp. 73-119. ISBN: 978-65-00-03030-3. https://doi.org/10.7476/9786500030303.0006.

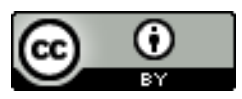

All the contents of this work, except where otherwise noted, is licensed under a Creative Commons Attribution 4.0 International license.

Todo o conteúdo deste trabalho, exceto quando houver ressalva, é publicado sob a licença Creative Commons Atribição 4.0.

Todo el contenido de esta obra, excepto donde se indique lo contrario, está bajo licencia de la licencia Creative Commons Reconocimento 4.0. 


\title{
Capítulo IV \\ Plantas medicinais: os saberes locais entre os camponeses da comunidade da Fazenda Engenho Novo, São Gonçalo/RJ
}

\author{
Luiz Henrique Marinho Lages \\ Juliana Riane Chagas \\ Marcelo Guerra Santos
}

\section{Humanidade, cultura e natureza}

O Homem vive da natureza, isto significa que a natureza é o seu corpo com o qual ele deve permanecer em processo constante, para não perecer. $\mathrm{O}$ fato de que a vida física e espiritual do homem se relaciona com a natureza não tem outro sentido senão o de que a natureza se relaciona consigo mesma, pois o homem é parte da natureza.

(Karl Marx, Manuscritos econômico-filosóficos)

As populaçóes humanas precisam relacionar-se com o seu ambiente, realizando trocas materiais para sobreviverem, em um processo táo intenso que foi descrito por Marx como um "metabolismo" entre natureza e sociedade. Essa relação se dá, sobretudo a partir do trabalho, mas esse metabolismo é prejudicado quando o modo de produçáo separa o trabalhador dos recursos ambientais resultando na alienação da natureza, juntamente com a alienação do trabalho. É a partir daí que irá surgir uma falha metabólica en- 
tre a sociedade e o meio ambiente, que está na raiz dos problemas socioambientais que a sociedade enfrenta hoje (Foster, 2014).

E em condições onde essa alienação da natureza não se encontra tão engessada, como nas populaçóes camponesas que realizam trocas mais intensas com o seu meio local, como no caso do assentamento da Fazenda Engenho Novo em São Gonçalo, como se dão as inter-relações entre uma população humana e o seu meio ambiente? A Etnobiologia, ciência que estuda, entre outros aspectos, a construção do conhecimento biológico de grupos humanos acerca de seus ambientes pode responder a essa pergunta, partindo de um conjunto de premissas (Albuquerque e Medeiros, 2013):

a) Uma parte do comportamento humano, relacionado ao uso de recursos naturais, evolui por meio da seleção de traços que conferem vantagens adaptativas ao ambiente.

b) Uma parte considerável da variabilidade comportamental é herdada por uma base cultural.

A cultura pode ser entendida como uma forma de intermediar as relaçóes entre sociedade e ambiente, afetando os processos ecológicos do ambiente ("transformação da natureza"), como também as relaçóes sociais de organização da produção ("transformação da sociedade"), ela própria também sendo modificada pela interação entre esses processos. Soldati (2013, p. 41), no âmbito da etnobotânica, iguala cultura ao aprendizado social, cuja definição é "o processo pelo qual as informaçóes são transmitidas em um grupo social a partir de interação entre seus pares, ou destes com os produtos da interação" (Boyd e Richardson, 2005; Mesoudi e Whiten, 2008; Soldati, 2013). Dessa forma, para entender como é construída a inter-relação entre um grupo humano e o seu ambiente, torna-se imprescindível saber como é realizado o processo de aprendizado social, logo, se faz necessário compreender a 
organização social do referido grupo, o que implica entender sua constituição histórica e suas relaçôes materiais com o ambiente.

Tendo em vista esses pressupostos, para responder à pergunta do presente trabalho - qual é e como é construído o conhecimento local sobre as plantas medicinais pelos agricultores da Fazenda Engenho Novo? -, faz-se necessário detalhar o processo de formação dessa comunidade, bem como seus processos de aprendizado social e o histórico de suas relaçôes com o ambiente físico da região (veja no capítulo 1 deste livro).

\section{Ciência, sociedade e plantas medicinais}

Do ponto de vista institucional, a Política Nacional de Plantas Medicinais e Fitoterápicos tem por finalidade "garantir à população brasileira o acesso seguro e o uso racional de plantas medicinais e fitoterápicos, promovendo o uso sustentável da biodiversidade, o desenvolvimento da cadeia produtiva e da indústria nacional", reconhecendo o uso e o manejo desses recursos pelas populaçóes tradicionais, conforme explicitado nos seguintes objetivos (Brasil, 2009, p. 11):

Promover e reconhecer as práticas populares e tradicionais de uso de plantas medicinais e remédios caseiros.

Promover o uso sustentável da biodiversidade e a repartição dos benefícios decorrentes do acesso aos recursos genéticos de plantas medicinais e ao conhecimento tradicional associado.

Ainda segundo o referido documento, em sua décima diretriz, "promover e reconhecer as práticas populares de uso de plantas medicinais e remédios caseiros", cabe aos Ministérios da Cultura, do Meio Ambiente e da Saúde, como gestores de açáo, "apoiar as iniciativas comunitárias para a organização e o reconhecimento dos conhecimentos tradicionais e populares". Entende- 
-se, assim, que este estudo pode embasar a comunidade para esse reconhecimento. Albuquerque e Hanazaki (2006, p. 684) destacam que:

Apesar da grande necessidade de estudos etnodirigidos para permitir a recuperação e a conservação de conhecimentos sobre plantas medicinais nativas no Brasil, [...], existe quase que uma completa ausência do uso ou desenvolvimento de teorias para abarcar os fenômenos observados e fazer avançar ainda mais rápido uma teoria da relação entre pessoas e os recursos naturais usados em sua medicina.

Entendendo que uma abordagem científica necessita de um corpo teórico para ser capaz tanto de responder questóes pertinentes ao estudo como de prever fenômenos e também apresentar algum grau de replicabilidade (Albuquerque e Hanazaki, 2006), faz-se necessário que, além de uma simples listagem de plantas medicinais, também sejam testadas hipóteses, a fim de se constituir teorias capazes de melhorar o poder explicativo da etnobiologia. Dentro desse contexto, Albuquerque e Medeiros (2013) ressaltam que os estudos etnobotânicos não devem se apartar de estudar as diferentes interaçóes entre o ser humano e o ecossistema no espaço e no tempo, indo além da abordagem utilitária classicamente adotada. Outro aspecto a ser levado em conta é a pressão por urbanização, da qual as comunidades acabam sendo alvo constante. Quanto a isso, Medeiros et al. (2013, p. 30) dizem que:

Os estudos atuais da dinâmica socioecológicos em contexto de urbanização ou de migraçôes podem fornecer informaçóes relevantes para entendermos determinados processos, uma vez que tais contextos remetem a mudanças muito mais rápidas e, portanto, mais facilmente capturáveis do que sistemas ecológicos mais estáveis. 
Soldati (2013) destaca que existem poucos estudos sobre como o conhecimento tradicional é transmitido, mas estes apontam para a prática das atividades diárias em comunidades rurais, de forma geral. Além disso, o mesmo autor ressalta que os estudos etnobotânicos, por tratarem dos conhecimentos locais, têm alto potencial para auxiliar no entendimento de como ocorre a socialização de informaçôes, ou seja, a evolução cultural. Ele propóe uma abordagem metodológica baseada no conceito de memória episódica, fundamentada na abordagem sistêmica da memória proposta por Tulving (1985), devido ao fato de esse tipo de memória estar associado às singularidades de um evento vivenciado por um indivíduo, o que aumentaria a especificidade dessa abordagem.

Este é um estudo de natureza quantitativa e qualitativa sobre os processos de aprendizado de saberes locais dentro da categoria específica plantas medicinais, a partir de um olhar etnográfico, utilizando a hipótese da memória sistêmica para aumentar sua efetividade e levando também em conta aspectos sociais e históricos dos camponeses da comunidade da Fazenda Engenho Novo. Busca alcançar, inclusive, a valorização da identidade e dos aspectos culturais da população estudada, reforçando práticas ecologicamente equilibradas de utilização dos recursos, a partir da reapropriação do conjunto de práticas e saberes especificados dessa localidade, para que haja fortalecimento da coesão social, dos laços de solidariedade interna, de sua ressignificação social, a fim de fortalecer a autogestáo produtiva da comunidade.

\section{O assentamento da Fazenda Engenho Novo}

O assentamento está localizado na histórica Fazenda Engenho Novo, um importante patrimônio histórico da cidade de São Gonçalo - estado do Rio de Janeiro - que data do século XVIII. Os camponeses que atualmente habitam a área do assentamento compóem uma população de origem bastante heterogênea, con- 
tando com diversos descendentes dos antigos trabalhadores da fazenda, bem como lavradores de outras regióes, trabalhadores urbanos aposentados, moradores pobres de áreas periféricas, pequenos comerciantes e pessoas que escolheram viver em uma área rural. A região tem um intenso histórico de conflitos pelo uso da terra, e aquilo que os confere um caráter de unidade é a luta pela terra e pelo trabalho rural (veja os capítulos 1 e 2 deste livro).

\section{Como foi realizada a pesquisa}

O primeiro passo do trabalho foi a observação participante plena, que consiste numa análise de dentro da comunidade, e onde foram obtidos os primeiros dados qualitativos, conforme descrito por Albuquerque et al. (2010). Essa observação focou-se em aspectos relacionados à organização social, modo de produção, relação com o ambiente, e histórico de vida dos agricultores. A partir dessa observação, pôde ser estabelecida a problematização do estudo e a proposição de modelos explicativos. Também é com base na observação participante que foi estabelecida uma relação de confiança com os agricultores, denominada "raport" (Bernard, 2006). A amostragem do estudo seguiu um padrão específico, intencional e não probabilístico. $\mathrm{O}$ momento e local escolhidos para observação foi a reuniáo mensal do Sindicato dos Trabalhadores Rurais de São Gonçalo, na área comum do assentamento, que são as ruínas do antigo casarão do Barão de São Gonçalo.

Durante o período de observação, foi feita a seleção dos "informantes", termo utilizado para designar as pessoas que serão alvo do estudo e que terão uma relação mais duradoura com a pesquisa, alguns sendo destacados como informantes chave ou especialistas locais. Albuquerque et al. (2010) colocam três pontos principais para a escolha do informante chave: 
1. A escolha não deve se basear na quantidade de informações fornecidas, mas na "sutileza dessas informaçōes".

2. Uma única informação, porém peculiar, pode justificar a escolha de um informante chave.

3. Além das informaçôes coletadas formalmente, detalhes informais ("nas entrelinhas"), porém significativos, justificam a escolha de um informante chave, contanto que sejam também relatados pelo pesquisador.

No caso do presente trabalho, os informantes chaves foram as pessoas que reconhecidamente dentro de sua comunidade são excelentes coletoras e/ou conhecedoras de plantas medicinais, e doravante seráo chamadas "especialistas locais". Estes foram encontrados primeiro pela observaçáo participante e em seguida por meio da técnica conhecida na literatura como "Bola de neve" (Bailey, 1994), que é uma forma de seleção intencional da amostragem, onde é pedido a cada especialista local que indique outro que ele conheça. $\mathrm{O}$ tamanho da amostra foi limitado pela quantidade de especialistas locais indicados dessa forma.

Os especialistas passaram por uma entrevista semiestruturada, onde foram relatados dados sobre sua origem, a maneira como aprendeu a utilizar as plantas e outras características socioeconômicas (se mora com a família, se vive da terra). Também foi perguntado a cada informante uma "lista-livre" das plantas que conhece/utiliza medicinalmente. Essa metodologia é utilizada nas ciências sociais e se baseia nos seguintes pressupostos: (1) as pessoas que são entrevistadas tendem a listar os termos por ordem de familiaridade; (2) pessoas que sabem mais sobre um domínio tendem a citar mais que pessoas que sabem menos; (3) termos mais citados indicam itens mais proeminentes ou salientes localmente (Albuquerque et al. 2010, p 53).

Segundo Quinlan (2005), essa metodologia pode ajudar tanto a encontrar os especialistas locais quanto a investigar 
as variaçóes dentro de um dado domínio cultural. Um de seus problemas é a falta de memória do informante, que pode omitir informaçóes valiosas. Nesse caso, Brewer (2002) sugere técnicas complementares como a induçáo não específica, que consiste em indagar o informante após ele completar a lista, ou a sugestão semântica, onde é perguntado ao informante se ele conhece plantas similares às que ele citou na lista.

A partir das listas de plantas medicinais produzidas pelas informações dos especialistas locais, foi realizada uma análise de similaridade entre o conhecimento dos informantes. Essa ferramenta é útil para relacionar a história de vida e as observaçôes com o conhecimento botânico construído. Para isso, foi calculado o Índice de Sorensen e a construção de dendrogramas, com o auxílio do programa Fitopac 2.1 (Sheperd, 2009).

Coletas botânicas foram realizadas, e o material testemunho, depositado no herbário da Faculdade de Formação de Professores da UERJ (RFFP). Esse passo é muito importante, pois estabelece uma ligação central entre o conhecimento científico e o conhecimento local, além de permitir que outros pesquisadores possam acessar o material coletado (Santos et al., 2012).

O trabalho foi submetido ao comitê de ética da UERJ, por meio da Plataforma Brasil, sendo autorizado com o CAAE: 43704215.6.0000.5282. Os informantes, relacionados aqui de forma anônima, serão indicados por letras maiúsculas, em ordem alfabética. A todos foi pedido o preenchimento de um termo de consentimento livre e esclarecido na participação da pesquisa, e assinou como testemunha um representante do sindicato ou outro agricultor que não tenha participado da pesquisa. Em certos casos, os entrevistados solicitaram que algumas informaçóes fornecidas ficassem em sigilo, devido a diversas razóes, e esse desejo foi respeitado. 


\section{Os especialistas locais}

Foram localizados e entrevistados dez informantes que moram no assentamento da Fazenda Engenho Novo e arredores. Apesar de todos serem oriundos do estado do Rio de Janeiro, os dez informantes apresentaram origens em comunidades, todas no estado do Rio de Janeiro: apenas três informantes declararam serem nascidos e criados na regiáo onde hoje é o assentamento. Dois informantes são da área rural de Silva Jardim, dois são de Santo Antônio de Pádua, no norte fluminense, dois são de outras áreas de São Gonçalo e um declarou ser de Nova Friburgo.

Quanto ao gênero, houve certo equilíbrio, sendo seis homens e quatro mulheres. Esse dado se opóe ao que Albuquerque e Lucena (2004) propóem, ao referirem que o quintal e os arredores da casa são considerados espaços femininos. Esse dado pode estar associado ao processo de masculinização do meio rural, que é explicado pelo êxodo seletivo das mulheres para o meio urbano, e, de acordo com Camorano e Abramovay (1999), pode ser explicado pela expansão do setor de serviços urbanos, o trabalho desvalorizado pela família rural e a relação com a formação educacional.

Quanto à participação na produção agrícola, oito informantes são produtores rurais, sendo que as duas exceçóes são uma informante que mora nos arredores do assentamento e é uma aposentada rural, mas não possui nem terra, nem participa mais de qualquer atividade agrícola, e uma outra informante que chegou há pouco tempo na regiáo, trabalha na cidade, deixando a cargo do marido todas as atividades relacionadas ao sítio. No entanto, considera-se que mesmo não participando dessas atividades, elas ainda podem ser consideradas camponesas, dado seu histórico e modo de vida (Marques, 2008). Além disso, apenas seis informantes sáo de fato assentados rurais, o que reflete a questáo da precarização do acesso à terra pelos trabalhadores rurais (Alentejano, 2002). Três informantes complementam a renda familiar no 
meio urbano e quatro já são aposentados rurais, ocorrendo, assim, sete casos de combinação de renda (figura 1).

Figura 1. Quantidade de informantes por atividade econômica do assentamento da Fazenda Engenho Novo, São Gonçalo/RJ

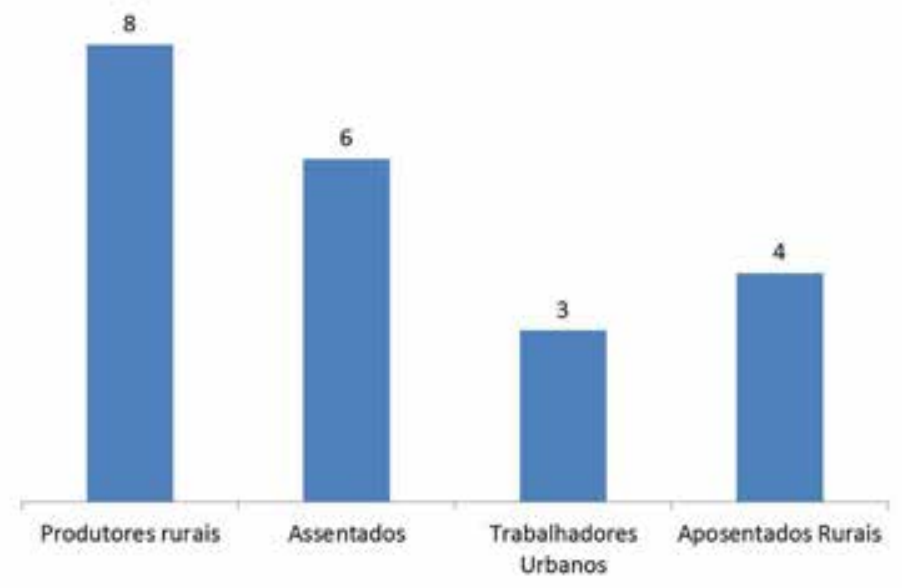

Fonte: Os autores.

Apenas um informante tem idade inferior a 40 anos, sendo sete com idade superior a 50 anos e seis com idade superior a 60 (figura 2). Em geral, essa é uma tendência apontada nos levantamentos etnobotânicos, ou seja, os membros mais velhos são os detentores do conhecimento sobre o uso das plantas medicinais (Ceolin et al. 2011). É importante também destacar o processo de envelhecimento da população rural brasileira, que ocorre desde a década de 1950, e pode ser correlacionado com o acesso a serviços básicos da cidadania, que são ainda "menos ruins" no meio urbano do que no meio rural (Camarano e Abramovay, 1999). Ademais, existe a questão da perda de interesse das geraçóes mais jovens com a vida rural, associada a uma desvalorização do campo, que se correlaciona a um modo de vida "atrasado", a péssimas condiçôes de trabalho e de vida (Godoy et al., 2011). 
A maioria dos informantes também apresenta baixa escolaridade: duas informantes nunca frequentaram escola; outros cinco tiveram experiência escolar no ensino fundamental; apenas três fizeram o ensino médio (figura 3). Esse fato também está de acordo com os indicadores de educação no campo no Brasil, que estão entre os mais baixos da América Latina (Camarano e Abramovay, 1999).

Figura 2. Faixa etária dos informantes da Fazenda Engenho Novo, São Gonçalo/RJ

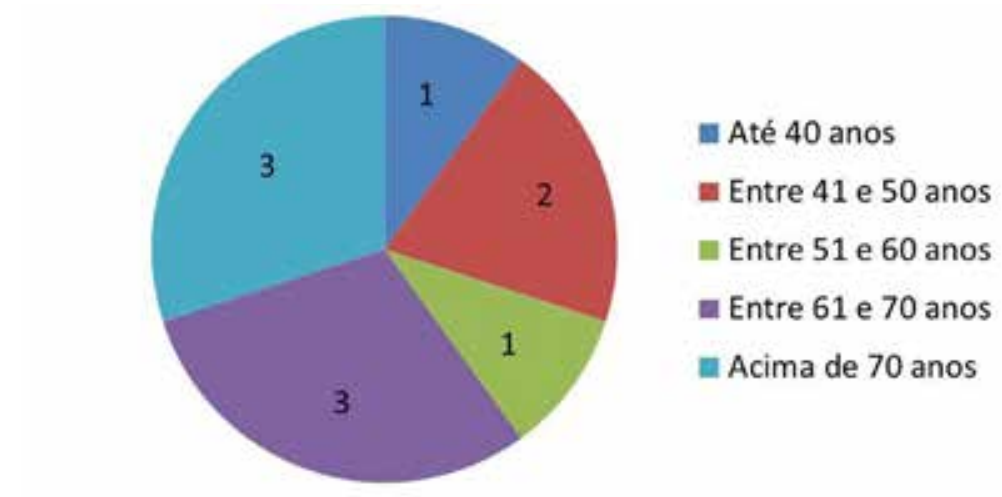

Fonte: Os autores.

Figura 3. Grau de escolaridade dos informantes da Fazenda Engenho Novo, São Gonçalo/RJ

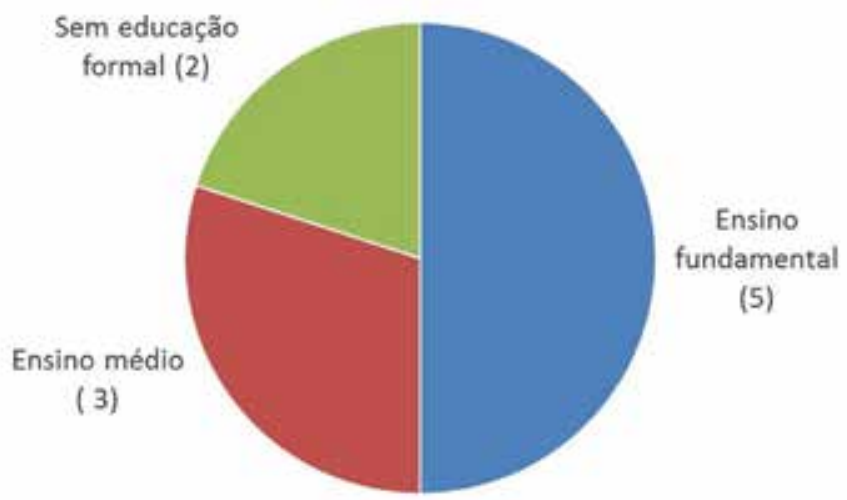

Fonte: Os autores. 


\section{As plantas medicinais citadas pelos agricultores}

\section{Plantas medicinais}

Das 111 espécies registradas, 76 foram identificadas cientificamente. Estas pertencem a 71 gêneros e 40 famílias botânicas, sendo um gênero (Lygodium) e uma família (Lygodiaceae) de samambaia e as demais de angiospermas. As famílias com maior representatividade em número de espécies foram Asteraceae (com sete espécies), seguida de Fabaceae e Lamiaceae (ambas com cinco espécies cada) (apêndice 1).

Do total de espécies citadas pelos informantes, 48 não foram coletadas (apêndice 1), por serem obtidas mediante a compra em mercados ou porque não estavam disponíveis durante o período das entrevistas. Em outros casos, a forma de obtenção não foi especificada, levando a sugerir que o indivíduo tem o conhecimento, mas náo utiliza a planta.

Quanto às etnoespécies, o quantitativo citado por cada informante foi o seguinte: "A" (16 etnoespécies), "B" (13), “C” (26), "D" (21), “E, F, G” (26), "H” (46), "I" (17) e o "J" (34) (apêndice 1). Vale ressaltar que os informantes $\mathrm{E}, \mathrm{F}, \mathrm{G}$ moram juntos e não foi possível separá-los durante as entrevistas, desse modo, todos os três citaram as mesmas espécies.

As espécies mais citadas pelos informantes foram saiăo ( 9 citaçôes), seguidas por erva-de-Santa Maria (8 citaçôes), arnica e trançagem (ambas com 7 citações) e aroeira, babosa, boldo, cana-do-brejo, erva-cidreira, picão (6 citaçóes cada) (apêndice 1).

\section{Indicaçáo de uso medicinal e sistemas abordados}

A indicação corresponde ao sintoma físico ou ao órgão do corpo no qual a planta tem ação (pode ser encontrado no apêndice 1). Algumas citaçóes usavam nomes diferentes para o mes- 
mo sintoma ou doença, como "gripe", "resfriado" e "antiviral". Em outros momentos, os termos indicavam situaçóes próximas, mas bem diferentes em termos práticos, como no caso de "cicatrizante" e "contusáo". O primeiro termo pareceu indicar feridas mais recentes, causadas por instrumentos cortantes, enquanto o segundo foi utilizado no sentido de pancadas, ou de feridas mais antigas (também chamadas "sangue pisado"). O termo "barriga de mulher" apareceu como um eufemismo para designar cólicas de menstruação, ou outros problemas relacionados ao aparelho reprodutor feminino, e foi colocado como sendo uma categoria de uso distinta.

Para simplificar a análise das indicaçóes, elas foram relacionadas aos diferentes sistemas corporais de acordo com as categorias da Classificação Estatística Internacional de Doenças e Problemas Relacionados à Saúde (CID 10), publicada pela Organização Mundial de Saúde (2000). A maioria das indicaçôes foi para distúrbios do sistema digestório (figura 4). Esse resultado é similar ao alcançado por Pinto et al. (2004), assim como por Amorozo (2002) e Almeida e Albuquerque (2002). Medeiros e Albuquerque (2013) destacam que esse fato se deve a duas características: (1) estas são as doenças mais recorrentes na comunidade, o que é justificado, já que inexiste saneamento básico na localidade; (2) o sistema digestório permite uma maior possibilidade de tratamento com compostos bioativos.

O conceito "doenças culturais" refere-se às manifestaçôes interpretadas como doenças e que não apresentam uma causa fundamentada cientificamente (Pinto et al., 2006), também denominadas de "doenças espirituais". Foram categorizadas, assim, dentro das doenças culturais as "Limpeza do corpo", "Corpo carregado", "Limpeza" e "Corpo ruim". 
Figura 4. Indicaçôes de uso das plantas medicinais, de acordo com os sistemas corporais relacionados (segundo a Organização Mundial da Saúde, 2000), no Assentamento da Fazenda Engenho Novo, São Gonçalo/RJ

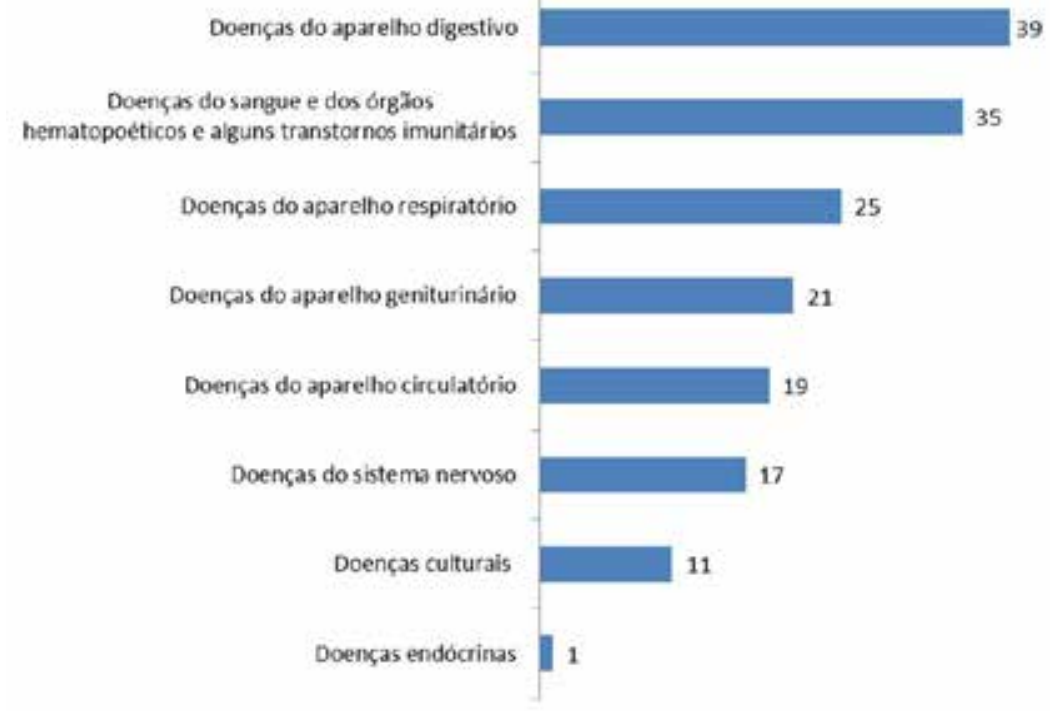

Fonte: Os autores.

\section{Objetivo do uso medicinal}

As plantas foram categorizadas por serem utilizadas para aliviar um sintoma ou para curar uma determinada moléstia. No entanto, no decorrer das entrevistas apareceram usos que não se enquadravam em nenhuma das duas categorias, como "abortivo" e "detetizante", mas que estavam sem dúvida relacionados a aspectos da saúde local. Aproximadamente $74 \%$ das indicaçóes tinham como objetivo aliviar um sintoma, enquanto cerca de $24 \%$ tinham como propósito a cura completa de um determinado problema (figura 5). Em pelo menos duas entrevistas, os informantes 
também relataram o uso de algumas plantas medicinais como parte regular da alimentação para prevenir o aparecimento de alguns problemas.

Figura 5. O objetivo do uso das plantas medicinais, segundo as citações dos informantes do Assentamento da Fazenda Engenho Novo, São Gonçalo/RJ

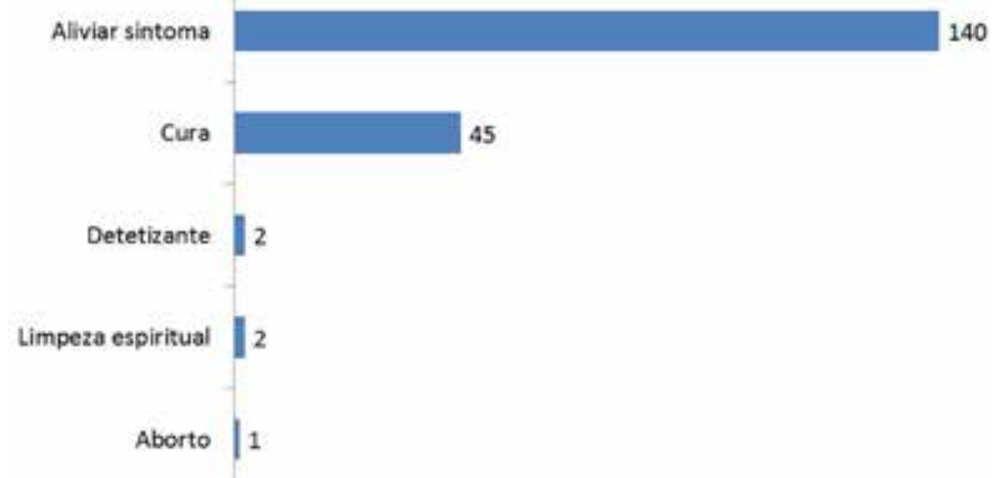

Fonte: Os autores.

\section{Parte da planta utilizada}

São utilizados folha, flor, fruto, raiz, a casca do caule ou uma combinação entre mais de um órgão (folha e flor, por exemplo) para uso das plantas medicinais (apêndice 1). Destas, o órgão mais importante foi a folha, com $80 \%$ das citações, seguida da casca com 5\% (figura 6). Para o maior uso da folha existem duas explicaçóes. A primeira, de acordo com Pilla et al. (2006), o uso da folha apresenta um caráter de conservação do recurso vegetal, pois não impede o desenvolvimento e a reprodução da planta, se a retirada da parte aérea não for excessiva. A outra explicação, de acordo com Franco e Barros (2006), tem a ver com o fato de que 
as folhas têm maior disponibilidade e é onde se concentram grande parte dos princípios ativos.

Figura 6. Partes vegetais utilizadas no preparo, de acordo com as citaçôes dos informantes do Assentamento da Fazenda Engenho Novo, São Gonçalo/RJ

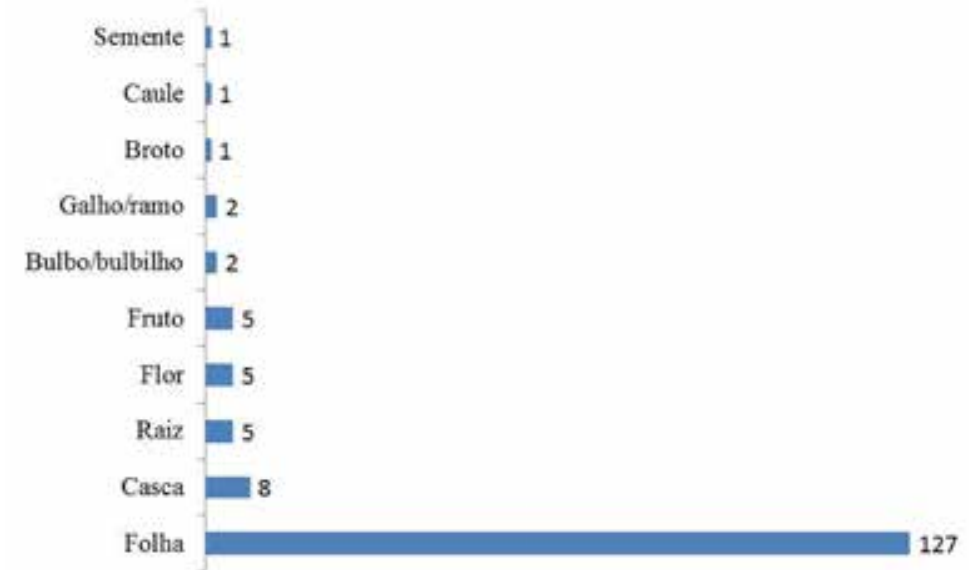

Fonte: Os autores.

\section{Formas de preparo e de uso das plantas medicinais}

A forma de preparo mais utilizada foi o chá, com $55 \%$ do total de citações. Do restante, emplastro teve $10 \%$, banho 9,6\%, maceração $6,8 \%$ e xarope $5,1 \%$ das citaçôes, e todas as outras tiveram menos de 3\% (figura 7). Esses resultados estão próximos aos de Azevedo et al. (2004), com uma maior incidência do uso de folhas e da decocção para o preparo das plantas.

Neste caso, a tabela do apêndice 1 representam uma simplificação muito grande da variedade de dados obtidos. A maioria dos informantes realiza os procedimentos de uma maneira muito espe- 
cifica, diferenciando-se em muitos detalhes, o que torna os procedimentos quase que únicos para cada informante. Por exemplo, ao pedir para que fosse explicado como era preparado um chá, um informante relatou que "a folha tem que ser colocada na água quente, mas sem ferver", enquanto outro relatou que "a folha tem que ser colocada na água fervente, mas em seguida deve-se desligar o fogo e deixar o recipiente abafado". Houve ainda relatos de que o chá deve ser tomado frio, ou que a água quente deve ser despejada direto no copo com as plantas. Muitos informantes diferenciaram que em algumas plantas o chá pode destruir o efeito, sendo necessário beber o "sumo" (no caso de folhas carnosas principalmente). Nesse caso, é necessário apertar ou espremer a folha ou fruto. No entanto, outros informantes relataram que o sumo pode ser obtido no liquidificador, ou ainda deixando a folha emersa num pote de água de um dia para o outro. $\mathrm{O}$ termo xarope refere-se a uma mistura, às vezes de várias plantas, ou a um tipo de conserva, feita com mel e açúcar, ou apenas açúcar. Também foi utilizada a categoria garrafada, para indicar que a planta deveria estar em conserva junto com alguma bebida alcóolica (licor ou conhaque). Em alguns casos a composição completa da garrafada não foi informada, por envolver aspectos de natureza mística ou religiosa. Alguns detalhes envolvidos foram citados, como "cortar em forma de cruz", ou "colocar embaixo do travesseiro", por demonstrar aspectos simbólicos envolvidos nos procedimentos. O preparo do banho, um dos únicos que houve concordância entre os informantes, foi descrito como sendo preparado numa bacia ou balde, com água quente, onde são deixadas as folhas por um tempo até a água esfriar a uma temperatura agradável, para somente então tomar o banho.

As formas de uso correspondem a maneira como os preparados foram utilizados pelo informante. A maioria das plantas (154) é ingerida, enquanto 22 servem para uso tópico, principalmente sobre feridas, e apenas 17 são utilizadas para banho. Azevedo e Fonseca-Kruel (2004) associam a forma de uso do banho 
a plantas de uso ritualístico, e essa correlação também apareceu forte nos relatos dos informantes que citaram essa forma de uso.

Podemos sintetizar o modo de preparo das plantas medicinais pelos informantes da FEN do seguinte modo:

Chá: cozinhar (decocção) ou verter água fervente sobre a planta (infusão).

Maceração: colocar a planta, amassada ou picada mergulhada em água fria por um tempo.

Banho: banhar o corpo utilizando o chá.

Salada: ingerir a planta crua.

Xarope: preparar de forma espessa o açúcar e o chá da planta.

Emplastro: amassar as plantas (algumas vezes com água, óleo ou azeite) e aplicá-las diretamente sobre a parte afetada.

Compressa: embeber panos limpos no chá ainda morno e aplicar no local afetado.

Inalação: colocar as plantas (geralmente aromáticas) dentro de água quente e o inalar o vapor.

Loção: macerar a planta em óleo ou azeite.

Aroma: colocar a planta no ambiente ou dentro de um recipiente (geralmente de pano) para inalar os seus aromas.

Óleo: extrair o óleo da planta.

Garrafada: preparar fórmula medicinal com componentes de origem vegetal, mineral e animal, e complementar com elementos religiosos.

Gargarejo: fazer com o chá da planta.

Tópico oral: colocar a planta ou o sumo diretamente sobre a mucosa oral ou dentes.

Defumador: jogar sobre brasas as plantas para queimar, o que libera uma fumaça aromática. 
Figura 7. As diferentes formas de preparo das plantas medicinais, de acordo com as citaçóes dos informantes do Assentamento da Fazenda Engenho Novo, São Gonçalo/RJ

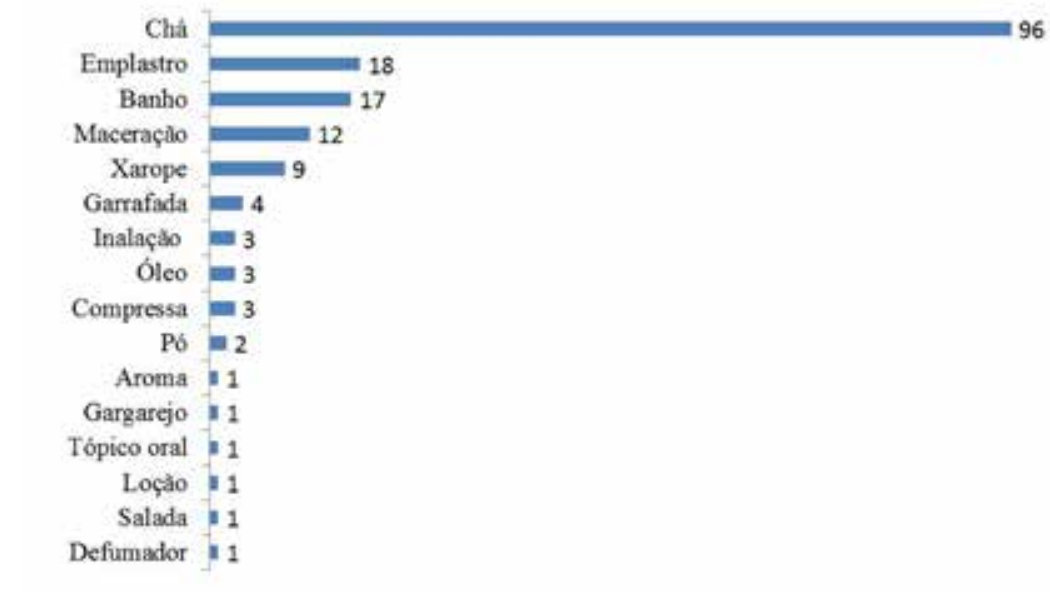

Fonte: Os autores.

\section{Uso da planta pelos informantes}

A coluna "faz uso" na tabela do apêndice 1 indica se o informante faz ou se já fez uso daquela planta. Em alguns casos, os informantes não especificaram, enquanto em outros eles afirmaram que conhecidos ou parentes fazem uso, mas que eles mesmos nunca precisaram fazer. No entanto, indiferente ao fato de terem usado pessoalmente ou por pessoas próximas, os informantes deixaram claro que indicam as plantas para outras pessoas. $\mathrm{O}$ elemento materno pareceu ser muito importante nessa questáo, pois muitos responderam: "nunca usei, mas minha mãe usava". Nesse caso, em $74 \%$ das citaçóes, os informantes afirmaram que sim, fazem uso das plantas citadas, enquanto em $29 \%$ das citaçóes a mãe deles fazia uso, e $7 \%$ eram conhecidos, ao passo que em apenas $4 \%$ das citaçóes eles afirmaram somente terem ouvido falar do uso da planta. 


\section{Forma de obtenção das plantas medicinais}

Em relação ao lugar onde os informantes conseguem as plantas citadas, são coletadas $49 \%$ delas, enquanto $22 \%$ são cultivadas, e apenas um total de $6 \%$ são compradas, seja em mercados ou casas de ervas.

Com relação à coleta, o quintal representou a principal unidade da paisagem de onde as plantas são retiradas. Na maioria das vezes, foi observado que os informantes coletam a planta quando ela se encontra próxima a sua casa ou em algum lugar dentro do seu lote, mas não se preocupam em cultivá-la, utilizando aquelas que crescem espontaneamente. Os informantes relataram que costumam selecionar as plantas que irão ser arrancadas com base na sua utilidade, e, em alguns casos, eles podem mesmo facilitar a sua propagação e realizar um certo manejo. De maneira diferente, cultivo significa que há um trabalho intencional de produção da planta, que de outra forma talvez náo estaria na casa deles. De todos os informantes, apenas o sr. "J" realmente consegue remuneração a partir dessa produção, uma vez que ele trabalha vendendo mudas de plantas medicinais, enquanto o sr. " $\mathrm{H}$ " mantém uma produção para consumo próprio e também de familiares e vizinhos. Em alguns casos, não há nem produção, nem coleta, e a planta simplesmente é comprada. O que transpareceu nas entrevistas é que, nesse caso, a dificuldade de plantio pode ser elevada e sua importância grande o suficiente para justificar a compra. Alguns informantes não especificaram a forma de obtenção das plantas, seja porque estavam relembrando informaçóes muito antigas, que obtiveram em outras regiôes, como o sr. "B", seja porque estáo muito recentes na região e desenvolveram pouco vínculo com o local, embora lembrem do que aprenderam com os pais, como o caso da sra. "C". 


\section{Plantas tóxicas}

Entre as plantas utilizadas como medicinais pelos assentados da Fazenda Engenho Novo, duas espécies possuem registro de toxicidade na literatura, de acordo com Lorenzi e Matos (2008) e Kissmann e Groth (2000): guiné ou guiné-pipiu (Petiveria alliacea L.) e mamona (Ricinus communis L.) (apêndice 1).

As folhas da guiné-pipiu são utilizadas na forma de banho para "limpeza do corpo", enquanto as folhas da mamona são usadas na forma de compressa/banho para curar ou aliviar os sintomas de inchaço (apêndice 1). Ambas as espécies possuem substâncias tóxicas que podem ser letais se ingeridas (Matos et al., 2011). Entretanto, os assentados da Fazenda Engenho Novo se restringem ao uso externo dessas plantas, na forma de compressa ou banho, o que, a princípio, não parece oferecer risco a saúde.

Náo são raros os casos em que se emprega somente uma parte da planta com fins medicinais, enquanto as outras partes podem ser consideradas tóxicas ou apenas ser indicado o uso externo da planta. Nesse último caso, um exemplo clássico é o confrei (Symphytum officinale L. - Boraginaceae), planta medicinal com substâncias tóxicas que teve o seu uso oral proibido por órgãos governamentais de vários países. Entretanto, o seu uso externo como cicatrizante é permitido (Lorenzi e Matos, 2008). Dessa forma, o usuário deve utilizar apenas a parte da planta recomendada, seguindo a forma de preparo e o uso indicado sugeridos por um médico ou um conhecedor popular da comunidade. Marques et al. (1995) acredita que os principais motivos dos envenenamentos por espécies de plantas sejam a falta de conhecimento da população sobre o potencial tóxico das plantas e o manuseamento incorreto.

Os assentados da Fazenda Engenho Novo reportam que duas plantas têm propriedades tóxicas, o chá das folhas da erva-de-São-João (Ageratum conyzoides L.), usado como abortivo, e o 
pião-roxo (Jatropha gossypiifolia L.), em que a seiva (látex) do caule é gotejada no dente para matar o seu nervo (apêndice 1).

Ageratum conyzoides é uma planta medicinal com atividades analgésica, anti-inflamatória e antirreumática comprovadas. Entretanto, as flores dessa espécie produzem os alcaloides pirrolizidínicos, licopsamina e equinatina, que possuem ação hepatotóxica, sendo então recomendável o uso de plantas sem flores para fins medicinais (Lorenzi e Matos, 2008). Os assentados da Fazenda Engenho Novo utilizam as folhas para o preparo do chá abortivo (apêndice 1), ou seja, a parte da planta que não possui as substâncias tóxicas.

O uso oral de preparações caseiras de Jatropha gossypiifolia deve ser desaconselhado por conta da presença de substâncias tóxicas, principalmente nas sementes (Lorenzi e Matos, 2008).

Entre as espécies utilizadas pelos assentados da FEN, quinze possuem alguma contraindicação registrada na literatura (tabela 1). A maioria delas (nove espécies) é contraindicada para mulheres grávidas ou lactantes; são elas: arruda, boldo, café, capim-limão, espinheira-santa, macaé, mamão, quebra-pedra e romã.

Duas espécies são contraindicadas para o uso oral: babosa e o pião-roxo (tabela 1). $\mathrm{Na} F E N$, alguns assentados indicam o uso oral da babosa (macera com água, garrafada com mel e bate no liquidificador) e do piáo-roxo (pingar seiva no dente) - veja apêndice 1. Santos e Carvalho (2018) destacam a necessidade de um diálogo de máo dupla entre os saberes tradicionais e os saberes científicos. Segundo esses autores, a experiência que determinadas comunidades possuem em utilizar, cultivar, coletar e preparar as plantas medicinais pode ser esclarecedora para a ciência, do mesmo modo que o conhecimento científico pode ser importante, principalmente na deteç̧ão de substâncias tóxicas ou na validação do uso de certas plantas medicinais. Desse modo, devem ser planejadas estratégias futuras para o intercâmbio de informaçóes 
entre os resultados dessa pesquisa e os assentados da Fazenda Engenho Novo.

Tabela 1. Plantas citadas pelos especialistas da Fazenda Engenho Novo com alguma contraindicação na literatura

\begin{tabular}{|c|c|c|}
\hline Nome popular & Nome científico & Contraindicação \\
\hline Aroeira & Schinus terebinthifolia & $\begin{array}{l}\text { Pode provocar fenômenos alérgi- } \\
\text { cos na pele e mucosas. }\end{array}$ \\
\hline Arruda & Ruta gaveolens & $\begin{array}{l}\text { Não é indicado para mulheres grá- } \\
\text { vidas e evitar exposição ao sol. }\end{array}$ \\
\hline Babosa & Aloe vera & $\begin{array}{l}\text { Não deve ser ingerida, pois pos- } \\
\text { sui substâncias (antraquinonas) } \\
\text { que podem causar grave crise de } \\
\text { nefrite aguda, entereocolites e he- } \\
\text { morroidas. }\end{array}$ \\
\hline Boldo & Plectranthus barbatus & $\begin{array}{l}\text { Não é indicado para mulheres grá- } \\
\text { vidas e crianças até } 12 \text { anos. }\end{array}$ \\
\hline Café & Coffea arabica & $\begin{array}{l}\text { Não é indicado para mulheres grá- } \\
\text { vidas ou que estejam amamentando. }\end{array}$ \\
\hline Capim-limão & Cymbopogon citratus & $\begin{array}{l}\text { Não deve ser utilizado por mulhe- } \\
\text { res grávidas. Evitar a presença de } \\
\text { microfilamentos da folha no chá, } \\
\text { que podem provocar lesões nas } \\
\text { mucosas que revestem o aparelho } \\
\text { digestivo. }\end{array}$ \\
\hline Erva-cidreira & Lippia alba & $\begin{array}{l}\text { Não é recomendado para pessoas } \\
\text { com pressão baixa e por crianças } \\
\text { entre } 0 \text { e } 5 \text { anos de idade. }\end{array}$ \\
\hline Espinheira-santa & Maytenus sp. & $\begin{array}{l}\text { Não é indicado para mulheres grá- } \\
\text { vidas ou em fase de amamentação. }\end{array}$ \\
\hline Macaé & Leonurus sibiiricus & $\begin{array}{l}\text { Nõ é indicado para mulheres grá- } \\
\text { vidas. }\end{array}$ \\
\hline Mamão & Carica papaya & $\begin{array}{l}\text { Seu fruto verde é considerado } \\
\text { abortivo. }\end{array}$ \\
\hline Milho & Zea mays & Pessoas com inflamação na próstrata. \\
\hline
\end{tabular}




\begin{tabular}{lll}
\hline Pinhão-roxo & Jatropha gossypiifolia & $\begin{array}{l}\text { Desaconselhável administração oral } \\
\text { desta planta. }\end{array}$ \\
\hline Quebra-pedra & Phyllanthus tenellus & $\begin{array}{l}\text { Não se deve fazer uso prolongado } \\
\text { (superior a 3 semanas) do chá de } \\
\text { quebra-pedra. Seu uso é contrain- } \\
\text { dicado em mulheres grávidas e que } \\
\text { amamentam, pois pode provocar } \\
\text { cólicas e diarreias no lactente. }\end{array}$ \\
\hline Romã & Punica granatum & $\begin{array}{l}\text { Não é indicado para mulheres grá- } \\
\text { vidas. }\end{array}$ \\
\hline Sete-sangrias & Cuphea carthagenenis & Crianças. \\
\hline
\end{tabular}

Fonte: Lorenzi e Matos, 2008.

\section{Similaridade de saberes entre os informantes}

Foi realizada uma análise de similaridade entre as diferentes listas produzidas por cada informante. No dendrograma apresentado na figura 8, podemos identificar três grupos: o primeiro formado pelos informantes "C", "J", "H", o segundo por "D", "E", "F", "G" e o terceiro por "A", "I" e o informante "B" isolado. A similaridade máxima encontrada foi de $45,8 \%$ (entre os informantes "D" e "E, F, G").

Os resultados se encontram dentro do esperado, mostrando maior similaridade entre o Sr. "A" e a Sra. "I", que são mãe e filho, e um maior distanciamento do Sr. "B" com os demais, uma vez que o conhecimento dele foi construído em outras regióes e no contato com outras pessoas que não são do assentamento.

Da mesma forma, os mais jovens (“C”, "J" e "H") apresentaram uma similaridade maior, devido a um contato maior com o meio urbano, ou seja, com fontes de conhecimento externas à comunidade. Medeiros e Albuquerque (2013) destacam que a proximidade com o meio urbano não necessariamente irá reduzir a quantidade de plantas utilizadas, mas poderá aumentá-las num 
primeiro momento, já que esse ambiente possibilita o contato com mais espécies exóticas.

O agrupamento entre o sr. " $D$ " e os informantes "E", "F" e "G" coincide com aqueles que relataram experiências de aprendizado individual nas entrevistas, mas também pode ser devido a um contato maior entre esses informantes, conforme observado no cotidiano.

Figura 8. Dendrograma de similaridade entre as diferentes listas de plantas medicinais citadas pelos informantes (A, B, C, D, E, F, G, H e I) no assentamento da Fazenda Engenho Novo, Sáo Gonçalo/RJ

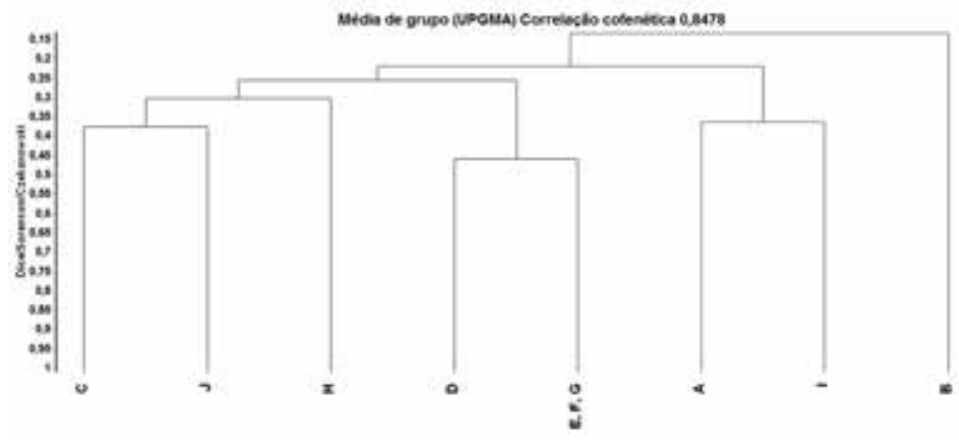

Fonte: Os autores.

\section{Consideraçóes finais}

Os camponeses do Assentamento Fazenda Engenho Novo possuem um conjunto de saberes acerca de plantas medicinais elevado, mas muitos se queixam que hoje a troca de informaçóes está menor. Além disso, o êxodo rural dos jovens e a desvalorização do papel dos saberes dos mais velhos podem estar levando a uma situação de erosão dessas práticas e saberes. São necessários mais 
estudos nessa direção para determinar em que medida esse problema está ocorrendo e suas possíveis soluçôes.

O Governo do Estado do Rio de Janeiro e a prefeitura de São Gonçalo têm usado a denominação "produtor rural" para os assentados da Fazenda Engenho Novo. Essa prática acaba reduzindo-os a uma condição de relação puramente econômica com a terra, negando a dimensão cultural e simbólica. É necessário que eles sejam reconhecidos como camponeses em plena acepção do termo, ou todos estes aspectos de sua cultura serão cada vez mais marginalizados em detrimento de outras influências que chegam até eles. A história dos camponeses deve ser contada.

\section{Referências}

ALBUQUERQUE, U. P. e HANAZAKI, N. "As pesquisas etnodirigidas na descoberta de novos fármacos de interesse médico e farmacêutico: fragilidades e perspectivas". Revista Brasileira de Farmacologia, v. 16, supl. 0, pp. 678-89, 2006.

e MEDEIROS, P. M. "Introdução à Etnobiologia de Bases Ecológicas e Evolutivas". In . (org.). Etnobiologia de Bases Ecológicas e Evolutivas. 1. ed. Recife: NUPEEA, 2013.

et al. "A Seleção dos participantes da pesquisa". In et al. (orgs.). Métodos e técnicas na pesquisa etnobiológica e etnoecológica. Recife: NUPEEA, 2010.

ALENTEJANO, P. R. R. "Luta por terra e reforma agrária no Rio de Janeiro". Revista Fluminense de Geografia, v. 1, n. 1, pp. 109-24, 2002.

ALMEIDA, C. F. C. B. R. e ALBUQUERQUE, U. P. "Uso e conservação de plantas e animais medicinais no estado de Pernambuco (nordeste do Brasil): um estudo de caso". Interciência, v. 27, n. 6, pp. 276-85, 2002.

AMOROZO, M. C. M. "Uso e diversidade de plantas medicinais em Santo Antonio do Leverger, MT, Brasil”. Acta Botanica Brasilica, v. 16, n. 2, pp. 189-203, 2002.

AZEVEDO, V. M e FONSECA-KRUEL, V. S. "Plantas medicinais e ritualísticas vendidas em feiras livres no Município do Rio de Janeiro, RJ, Brasil: estudo de caso nas zonas Norte e Sul". Acta Botanica Brasilica, v. 21, n. 2, pp. 263-75, 2007.

BAILEY, K. Methods of social research. New York: The Free Press, 1994. 
BERNARD, H. R. Research methods in anthropology: qualitative and quantitative approaches. 4. ed. Oxford: Altamira Press, 2006.

BOYD, E e RICHERSON, P. J. Not genes alone: how culture transformed human evolution. Chicago: University of Chicago Press, 2005.

BRASIL. Programa Nacional de Plantas Medicinais e Fitoterápicos. Brasília: Ministério da Saúde, 2009.

BREWER D. D. "Supplementary interviewing techniques to maximize output in free listing tasks". Field Methodologies, v. 14, pp. 108-18, 2002.

CAMARANO, A. A e ABRAMOVAY, R. Exodo rural, envelhecimento e masculinizaçâo no Brasil: panorama dos últimos 50 anos. Disponível em: http:// www.ipea.gov.br/portal/images/stories/PDFs/TDs/td_0621.pdf. Acesso em: 12 ago. 2015.

CEOLIN, T. et al. "Plantas medicinais: transmissão do conhecimento nas famílias de agricultores de base ecológica no Sul do RS". Revista da Escola de Enfermagem da USP, v. 45, n. 1, pp. 47-54, 2011.

FOSTER, J. B. A ecologia de Marx: materialismo e natureza. Rio de Janeiro: Civilização Brasileira, 2014.

FRANCO, E. A. P e BARROS, R. F. M. "Uso e diversidade de plantas medicinais no Quilombo Olho D'água dos Pires, Esperantina, Piauí". Revista Brasileira de Plantas Medicinais, v. 8, n. 3, pp. 78-88, 2006.

GODOY, K. E. "Circuito turístico da fazenda Engenho Novo: possibilidades para a preservação do patrimônio cultural, a valorização da comunidade local e profissionalização de atividades geradoras de renda". Anais do XXVI Simpósio Nacional de História. São Paulo: ANPUH, 2011.

KISSMANN, K. G. e GROTH, D. Plantas infestantes e nocivas, t. III. São Paulo: Basf, 2000.

LORENZI, H. e MATOS, F. J. A. Plantas medicinais no Brasil: nativas e exóticas. Nova Odessa: Instituto Plantarum, 2008.

MARQUES, M. B. et al. "Avaliação da Rede Brasileira de Centros de Controle de Intoxicação e Envenenamento - CCIEs". Cadernos de Saúde Pública, v. 11, n. 4, pp. 560-78, 1995.

MARQUES, M. I. M. A. "Atualidade do conceito de camponês". Revista NERA, v. 12, pp. 57-67, 2008.

MATOS, F. J. A. Plantas tóxicas: estudo de fitotoxicologia quimica de plantas brasileiras. Nova Odessa: Insituto Plantarum de Estudos da Flora, 2011.

MEDEIROS, P. M e ALBUQUERQUE, U. P. "Padróes de uso de plantas medicinais por populaçóes locais: o que pode estar por trás de nossas decisóes?” In ALBUQUERQUE, U. P. (org.). Etnobiologia: bases ecológicas e evolutivas. NUPPEA: Recife, 2013. 
et al. "As abordagens ecológico-evolutivas em etnobiologia: história e conceitos". In ALBUQUERQUE, U. P. (org.). Etnobiologia: bases ecológicas e evolutivas. Recife: NUPPEA, 2013.

MESOUDI, A e WHITEN, A. "The multiple roles of cultural transmission: experiments in understanding human cultural evolution". Philosophical Transactions of the Royal Society B, v. 363, pp. 3489-501, 2008.

ORGANIZAÇÃO MUNDIAL DA SAÚDE. Classificação Estatística Internacional de Doenças e Problemas Relacionados à Saúde: CID-10. São Paulo: EdUSP, 2000.

PILLA, M. A. C. et al. "Obtenção e uso das plantas medicinais no distrito de Martim Francisco, Município de Mogi-Mirim, SP, Brasil”. Acta Botanica Brasilica, v. 20, n. 4, pp. 789-802, 2006.

PINTO, E. P. P et al. "Conhecimento popular sobre plantas medicinais em comunidades rurais de Mata Atlântica - Itacaré, BA, Brasil”. Acta Botanica Brasilica, v. 20, n. 4, pp. 751-62, 2006.

QUINLAN, M. "Considerations for collecting freelists in the field: examples from Ethnobotany". Field Methods, n. 17, pp. 1-16, 2005.

SANTOS, M. G. et al. "A importância das coleçóes biológicas escolares para o conhecimento da riqueza biológica regional". Anais do I Encontro Nacional de Ensino de Biologia e III Encontro Regional de Ensino de Biologia RJ/ES. Rio de Janeiro: Sociedade Brasileira de Ensino de Biologia, 2005.

et al. "A biodiversidade da APA do Engenho Pequeno e Morro do Castro". In (org.). Estudos Ambientais em regióes metropolitanas: São Gonçalo. Rio de Janeiro: EdUERJ, 2012.

e CARVALHO, A. C. B. "Plantas medicinais: saberes tradicionais e o sistema de saúde". In e QUINTEIRO, M. (orgs.). Saberes tradicionais e locais: reflexóes etnobiológicas. Rio de Janeiro: EdUERJ, 2018.

SHEPHERD, G. J. FITOPAC 2.1. São Paulo: Universidade Estadual de Campinas/Departamento de Biologia Vegetal, 2009.

SOLDATI, G. T. Produção, transmissão e estrutura do conhecimento tradicional sobre plantas medicinais em três grupos sociais distintos: uma abordagem evolutiva (dissertação). UFRPE, 2013.

"Transmissão de Conhecimento: origem social das informações e da evolução cultural”. In ALBUQUERQUE, U. P. (org.). Etnobiologia: bases ecológicas e evolutivas. Recife: NUPPEA, 2013.

TULVING, E. "Memory and consciousness". Canadian Psychology/Psychologie Canadienne, v. 26, n. 1, pp. 1-12, 1985. 
Plantas medicinais:...

101

\begin{tabular}{|c|c|c|c|c|c|c|c|}
\hline 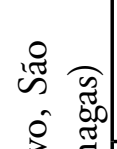 & 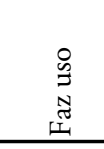 & & 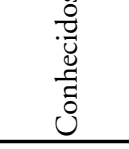 & 汽 & 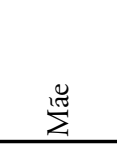 & $\Xi$ & $\Xi$ \\
\hline 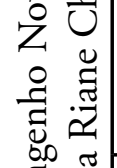 & 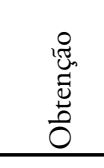 & & $\frac{\tilde{E}}{\Xi}$ & $\frac{\pi}{0}$ & 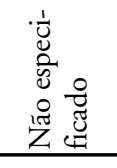 & 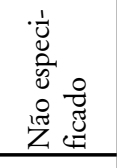 & 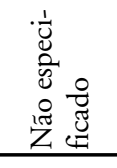 \\
\hline 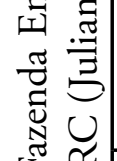 & 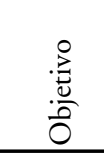 & & $\tilde{\Xi}$ & 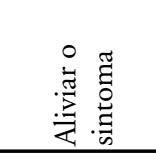 & $\stackrel{\widetilde{\Xi}}{\exists}$ & $\widetilde{\Xi}$ & $\widetilde{\Xi}$ \\
\hline 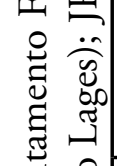 & 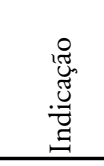 & & 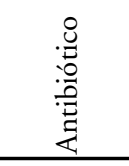 & $\stackrel{\Xi_{0}}{\nu}$ & 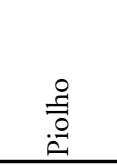 & 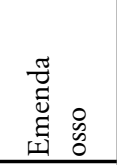 & 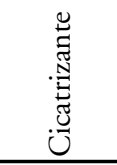 \\
\hline 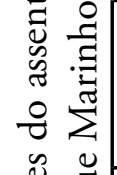 & 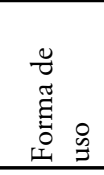 & & త్ & 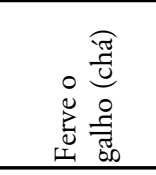 & 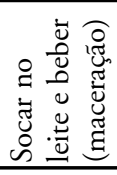 & 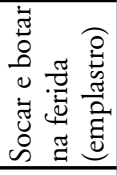 & 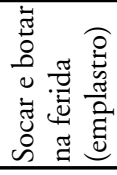 \\
\hline 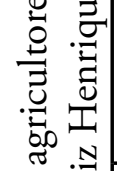 & 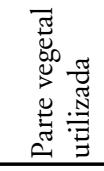 & & $\begin{array}{l}\stackrel{5}{0} \\
0 \\
\end{array}$ & 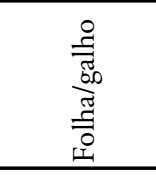 & $\begin{array}{l}\text { 픔 } \\
0 \\
\end{array}$ & $\begin{array}{l}\frac{\pi}{0} \\
\\
\end{array}$ & $\begin{array}{l}\stackrel{5}{0} \\
0 \\
\end{array}$ \\
\hline 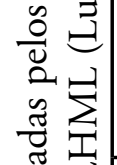 & $\frac{\overrightarrow{0}}{0}$ & & 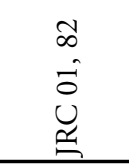 & 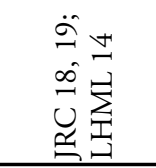 & & & \\
\hline 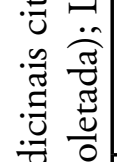 & 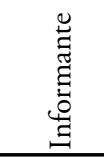 & & $n$ & 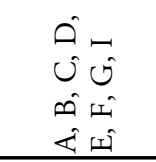 & & & \\
\hline 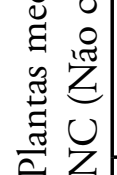 & 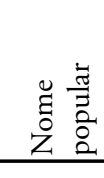 & & 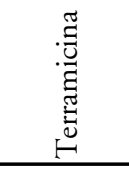 & 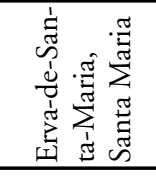 & & & \\
\hline 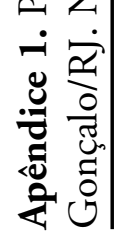 & 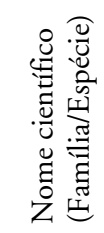 & 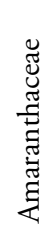 & 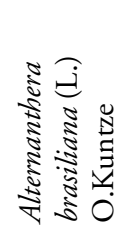 & 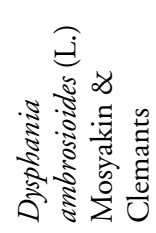 & & & \\
\hline
\end{tabular}


102 O rural em regiốes metropolitanas: a Fazenda Engenho Novo, São Gonçalo

\begin{tabular}{|c|c|c|c|c|c|c|c|c|c|}
\hline ह & 喅 & & 污 & 结 & : & $\Xi$ & $\stackrel{\Xi}{n}$ & 结 & $\Xi$ \\
\hline$\frac{\pi}{0}$ & $\begin{array}{l}\frac{\pi}{0} \\
0 \\
0\end{array}$ & & ن⿺辶卂 & 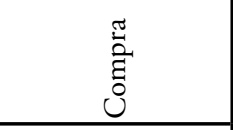 & $\frac{\pi}{0}$ & $\frac{\tilde{E}}{\tilde{E}}$ & $\frac{\tilde{a}}{3}$ & $\frac{\tilde{g}}{3}$ & $\frac{\pi}{0}$ \\
\hline 莺泀 & $\widetilde{\Xi}$ & & 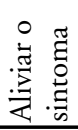 & 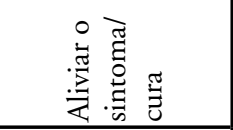 & 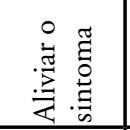 & $\stackrel{\widetilde{U}}{3}$ & $\tilde{\Xi}$ & $\widetilde{\Xi}$ & 苞泀 \\
\hline 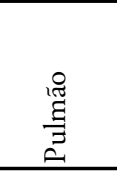 & 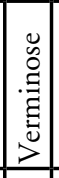 & & 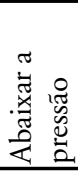 & 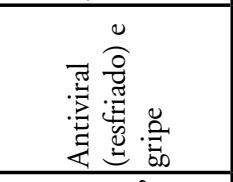 & 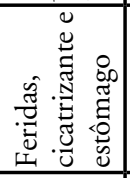 & 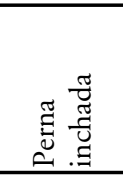 & 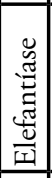 & 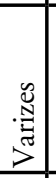 & 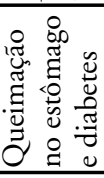 \\
\hline 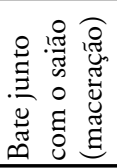 & 孚 & & 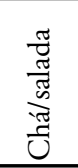 & 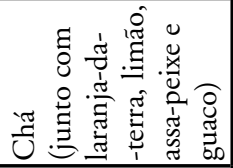 & $\stackrel{\pi}{0}$ & $\stackrel{\sim \pi}{0}$ & $\stackrel{\sim}{0}$ & 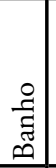 & $\frac{\mathfrak{g}}{0}$ \\
\hline $\begin{array}{l}\frac{\pi}{0} \\
\text { 인 } \\
\end{array}$ & $\begin{array}{r}3 \\
\overline{0} \\
0 \\
\end{array}$ & & $\stackrel{\circ}{\stackrel{\Rightarrow}{\ominus}}$ & 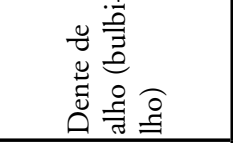 & $\begin{array}{l}\widetilde{J} \\
\tilde{J} \\
\tilde{J}\end{array}$ & $\begin{array}{l}\stackrel{3}{0} \\
\text { 豆 }\end{array}$ & $\begin{array}{l}\stackrel{\pi}{=} \\
0 \\
0\end{array}$ & $\begin{array}{l}\tilde{J} \\
\tilde{u} \\
\tilde{J} \\
\end{array}$ & $\begin{array}{l}\widetilde{J} \\
\tilde{J} \\
\tilde{J}\end{array}$ \\
\hline & & & Z & U & 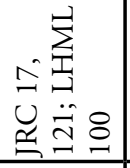 & 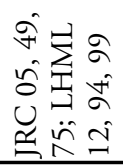 & & & \\
\hline & & & $I$ & $\begin{array}{l}I \\
\dot{U}\end{array}$ & $\begin{array}{l}0 \\
\stackrel{\omega}{\omega}\end{array}$ & $\begin{array}{l}\hat{\imath} \\
\hat{0} \\
\hat{U}\end{array}$ & & & \\
\hline & & & $\begin{array}{l}\frac{\pi}{0} \\
\frac{0}{0} \\
0\end{array}$ & $\stackrel{8}{\stackrel{2}{2}}$ & 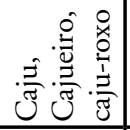 & 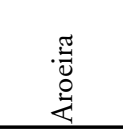 & & & \\
\hline & & 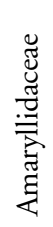 & 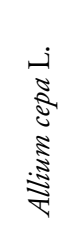 & 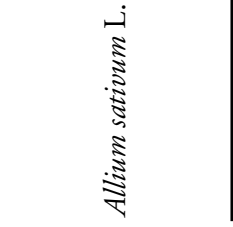 & 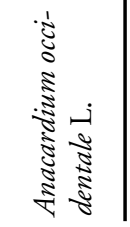 & 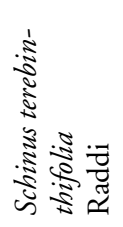 & & & \\
\hline
\end{tabular}


Plantas medicinais:... 103

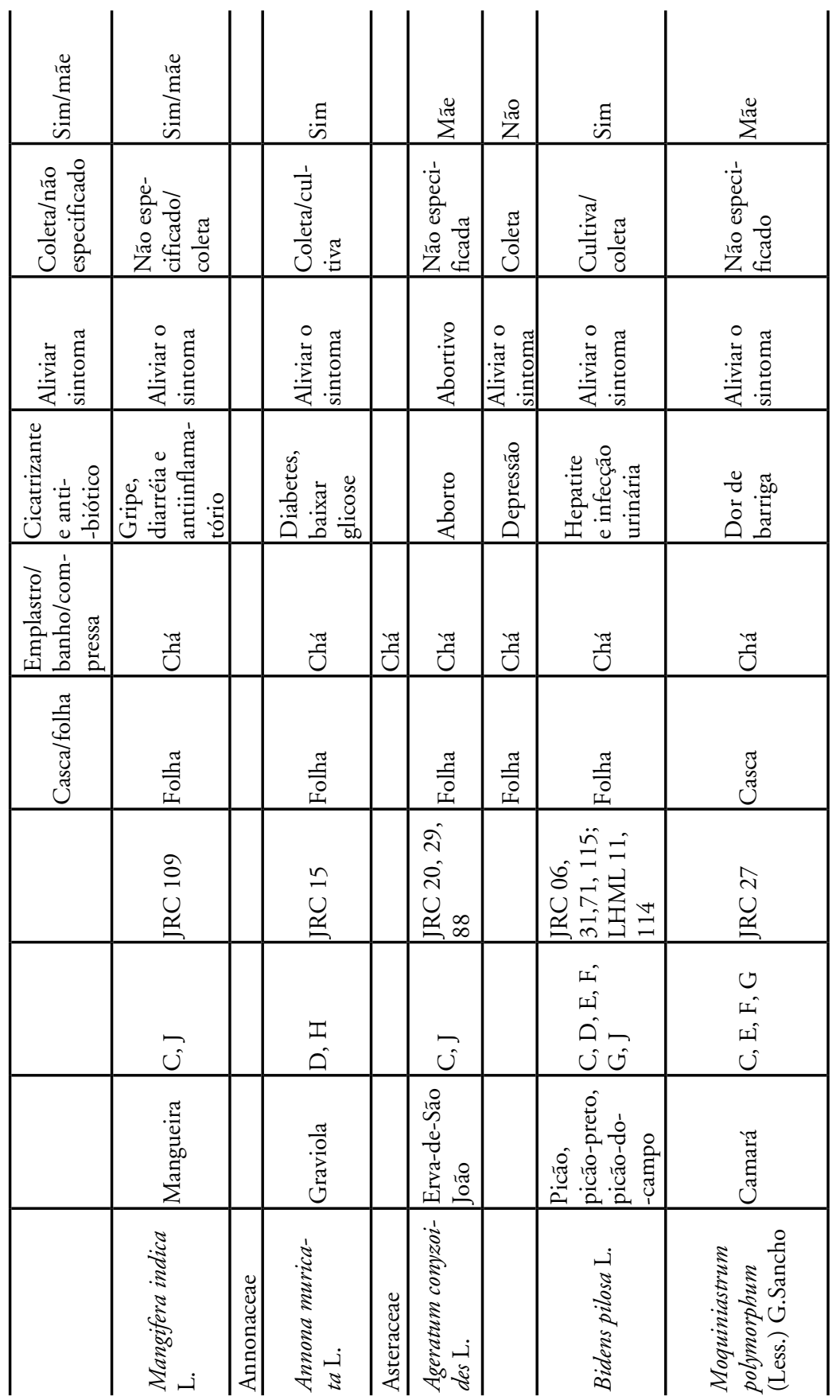


104 O rural em regióes metropolitanas: a Fazenda Engenho Novo, Sáo Gonçalo

\begin{tabular}{|c|c|c|c|c|c|}
\hline 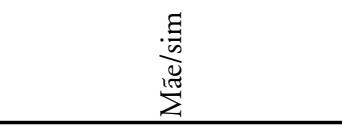 & 超 & $\Xi$ & 洁 & 兒 & 兒 \\
\hline 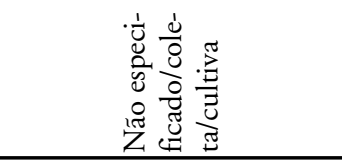 & 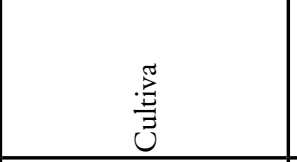 & $\frac{\pi}{0}$ & $\frac{\pi}{0}$ & $\frac{\pi}{0}$ & 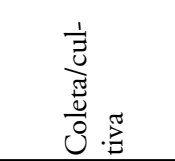 \\
\hline 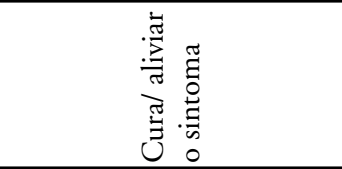 & 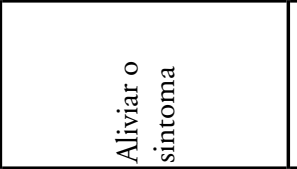 & Uี & 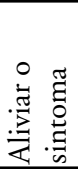 & 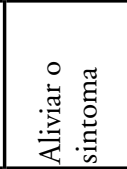 & 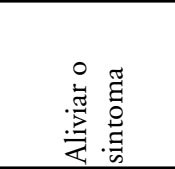 \\
\hline 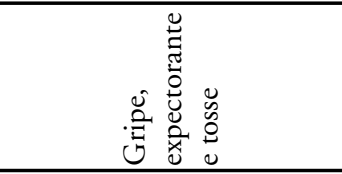 & 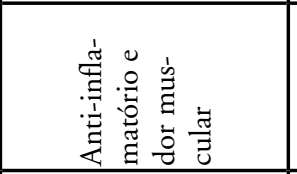 & 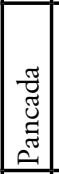 & 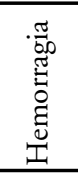 & 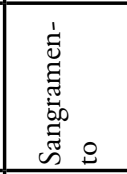 & 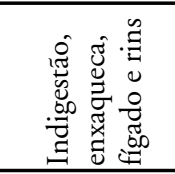 \\
\hline 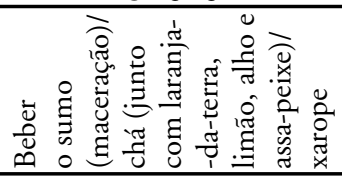 & 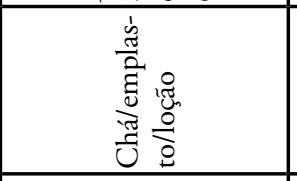 & $\frac{\pi}{0}$ & $\frac{\pi}{0}$ & 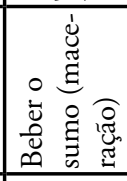 & 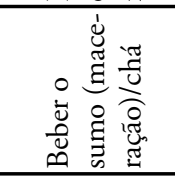 \\
\hline 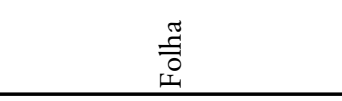 & $\begin{array}{l}\text { 寽 } \\
\text { 足 } \\
\end{array}$ & $\begin{array}{l}\frac{\pi}{0} \\
\overline{0} \\
\\
\end{array}$ & $\begin{array}{l}\stackrel{0}{=} \\
\stackrel{0}{0} \\
\end{array}$ & $\begin{array}{l}\frac{\pi}{5} \\
\frac{1}{0} \\
\end{array}$ & $\begin{array}{l}\stackrel{\pi}{7} \\
0 \\
\end{array}$ \\
\hline 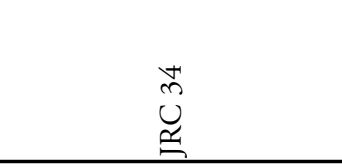 & 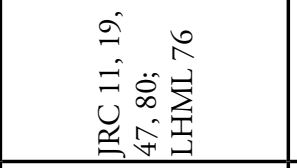 & & & & 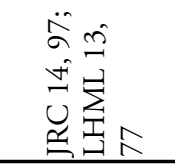 \\
\hline $\begin{array}{l}\overrightarrow{I^{2}} \\
\hat{0}\end{array}$ & 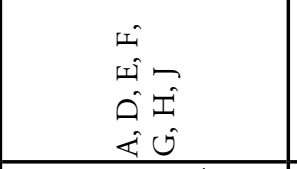 & & & & 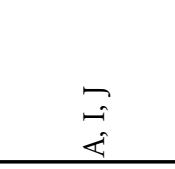 \\
\hline 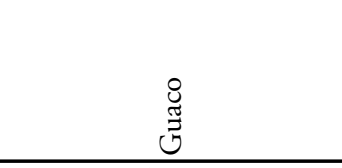 & 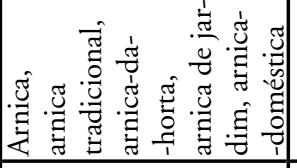 & & & & 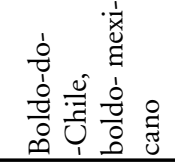 \\
\hline 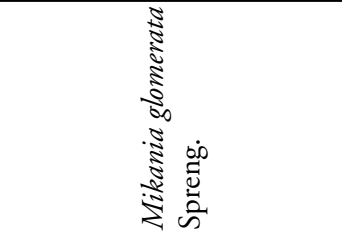 & 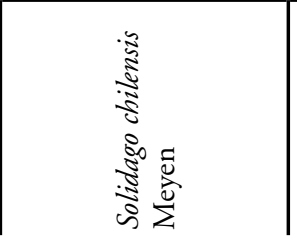 & & & & 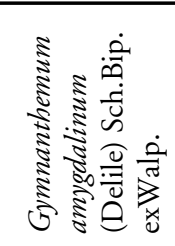 \\
\hline
\end{tabular}


Plantas medicinais:... 105

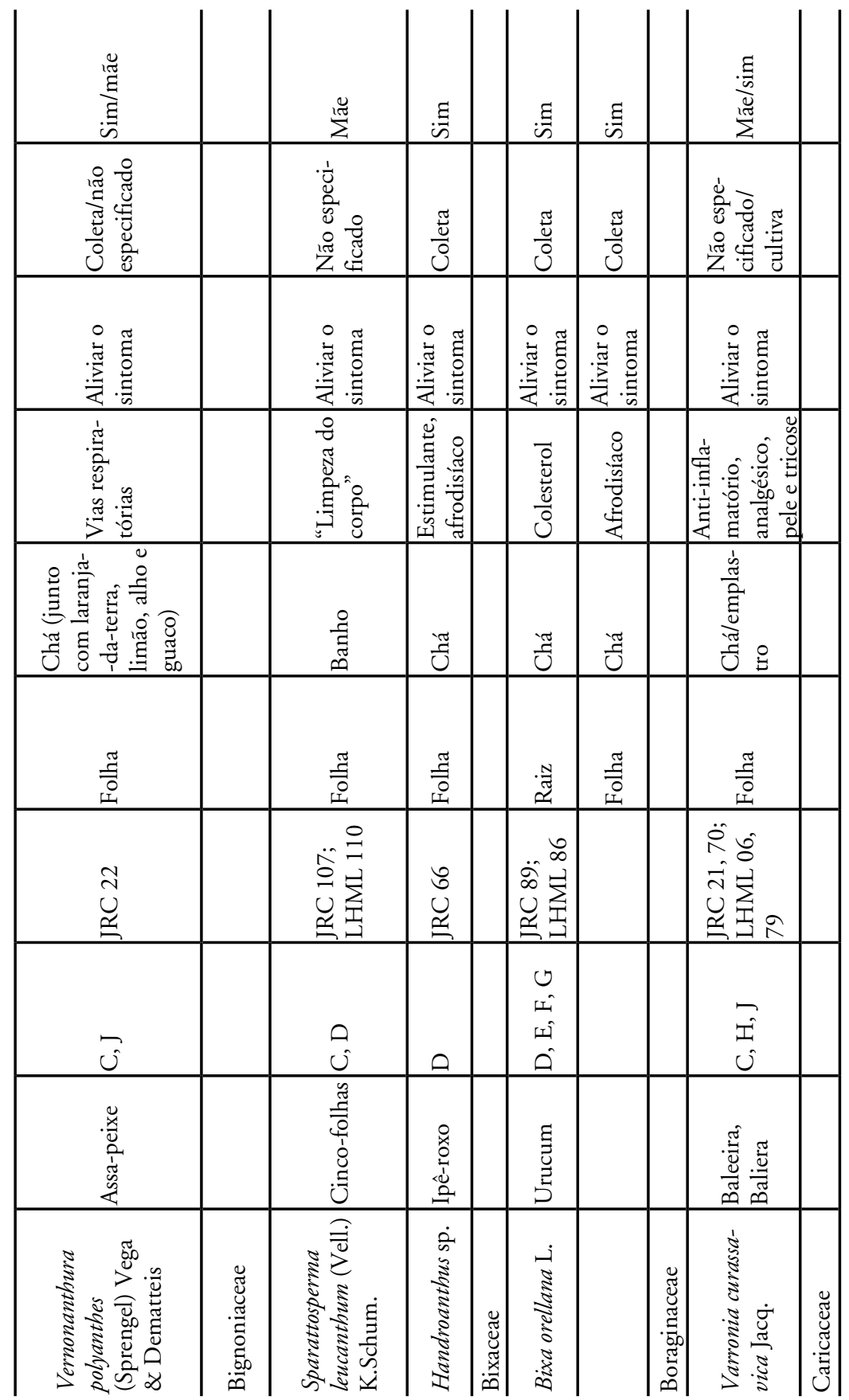


106 O rural em regiōes metropolitanas: a Fazenda Engenho Novo, São Gonçalo

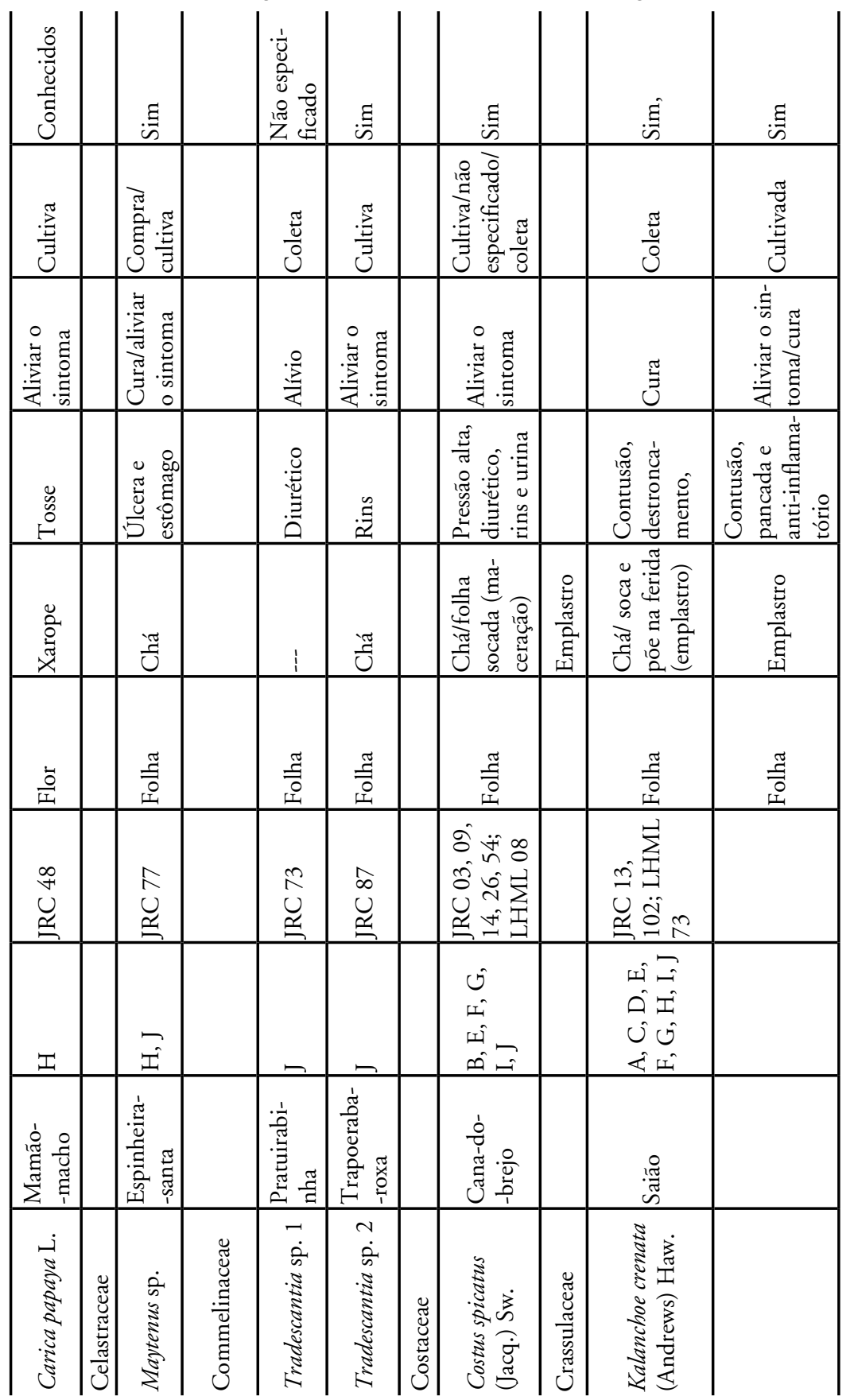


Plantas medicinais:...

107

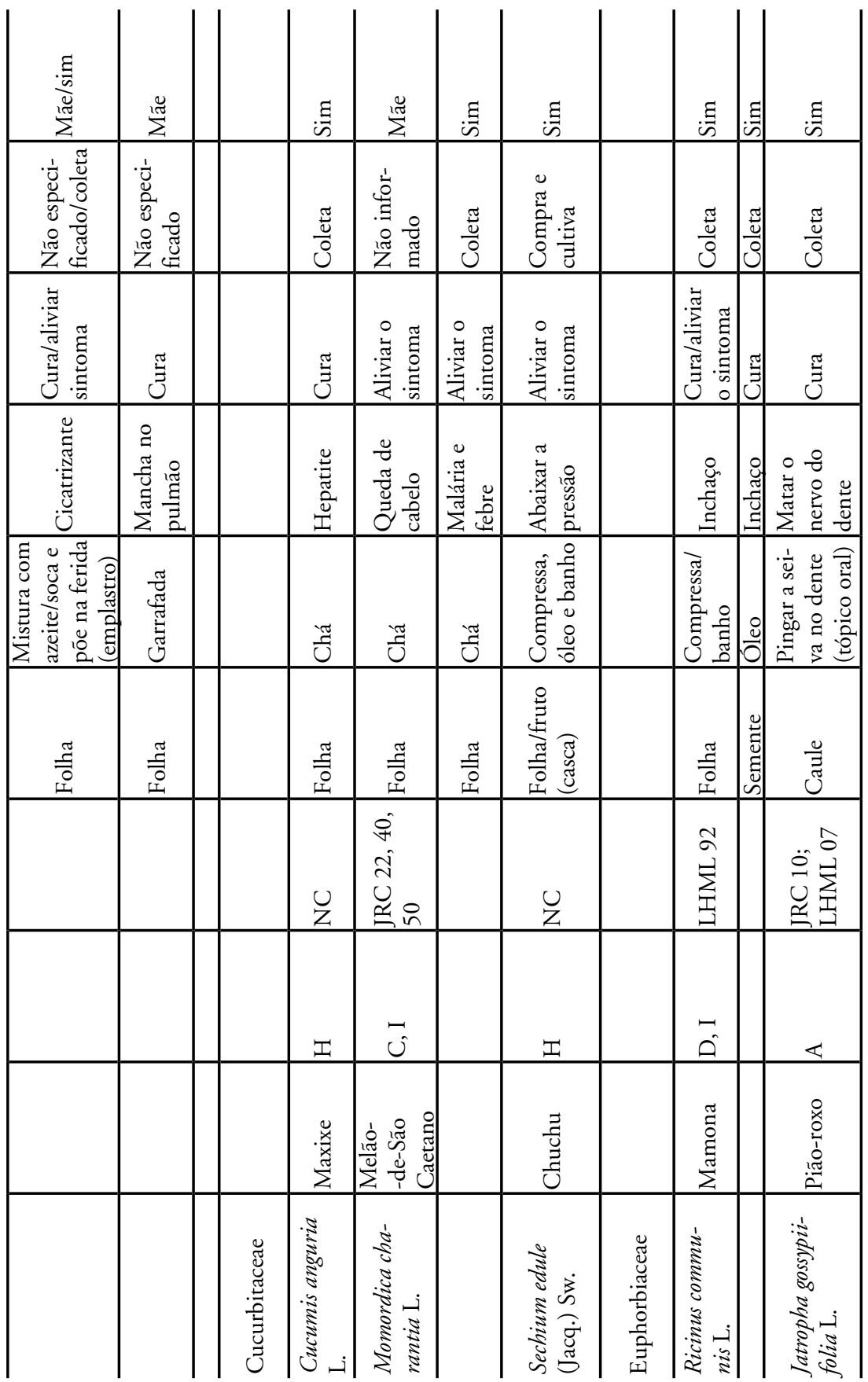


108 O rural em regiốes metropolitanas: a Fazenda Engenho Novo, São Gonçalo

\begin{tabular}{|c|c|c|c|c|c|c|}
\hline 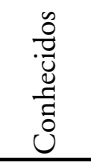 & & $\sum^{i \pi}$ & $\sum^{i \pi}$ & 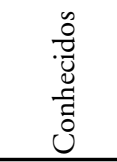 & 寻 & 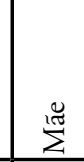 \\
\hline$\frac{\pi}{0}$ & & 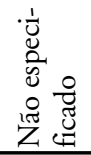 & 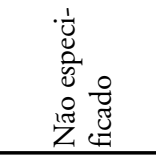 & $\frac{\pi}{0}$ & $\frac{\pi}{0}$ & 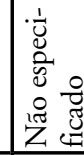 \\
\hline$\stackrel{\widetilde{G}}{3}$ & & 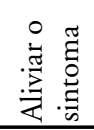 & 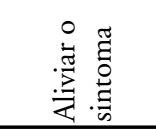 & $\tilde{\Xi}$ & 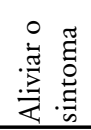 & 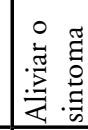 \\
\hline 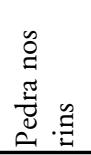 & & 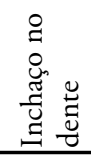 & 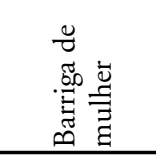 & 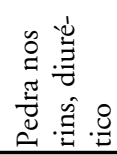 & 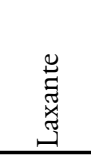 & ڤั๊ \\
\hline$\stackrel{\pi}{0}$ & & త్ & ] & $\frac{\pi}{0}$ & $\stackrel{\sim \widetilde{3}}{0}$ & $\underset{0}{0}$ \\
\hline $\begin{array}{l}\stackrel{\pi}{0} \\
0 \\
\end{array}$ & & $\begin{array}{l}\stackrel{0}{7} \\
\overline{0} \\
\end{array}$ & 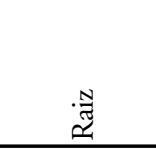 & $\begin{array}{l}\stackrel{0}{0} \\
\end{array}$ & $\begin{array}{l}\stackrel{\pi}{5} \\
0 \\
\end{array}$ & 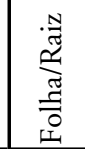 \\
\hline $\begin{array}{l}\widetilde{\sigma} \\
\underline{u} \\
\underline{ت}\end{array}$ & & $\begin{array}{l}\hat{0} \\
\hat{n} \\
\hat{n}_{n} \\
\tilde{c}\end{array}$ & 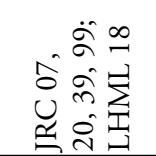 & & 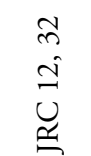 & \\
\hline$\varangle$ & & $u$ & $\begin{array}{l}0 \\
4\end{array}$ & & $\vec{v}$ & \\
\hline 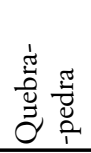 & & 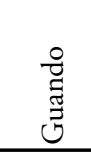 & 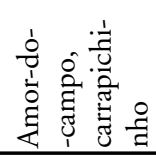 & & $\begin{array}{l}\frac{\pi}{\tilde{0}} \\
\cdot \frac{\pi}{\pi} \\
0 \\
0\end{array}$ & \\
\hline 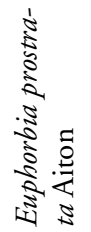 & 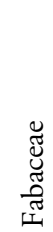 & 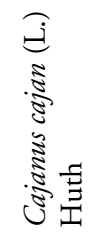 & 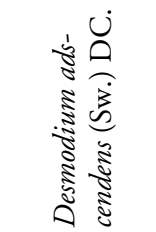 & & 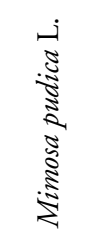 & \\
\hline
\end{tabular}


Plantas medicinais:... 109

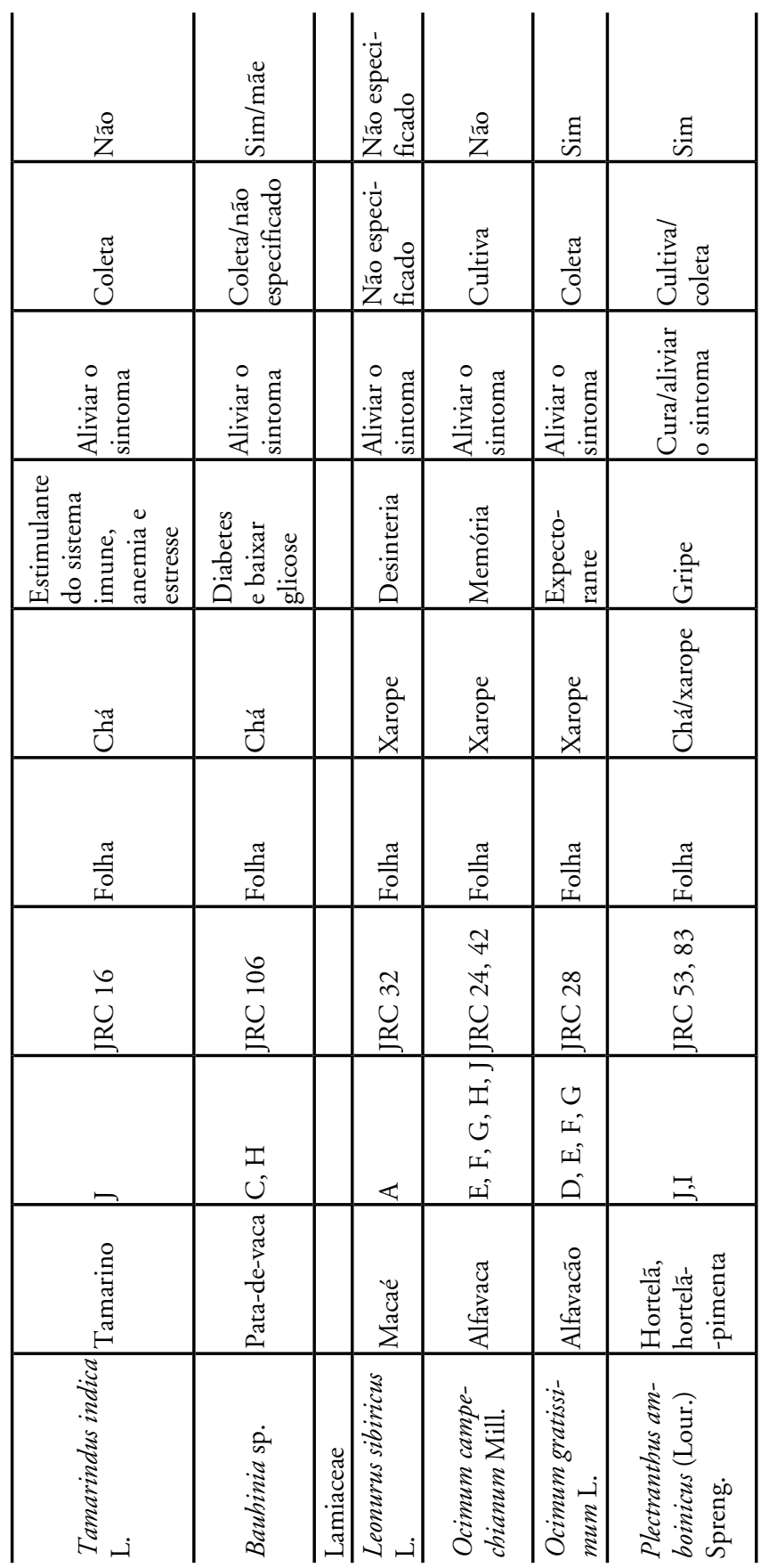


110 O rural em regióes metropolitanas: a Fazenda Engenho Novo, Sáo Gonçalo

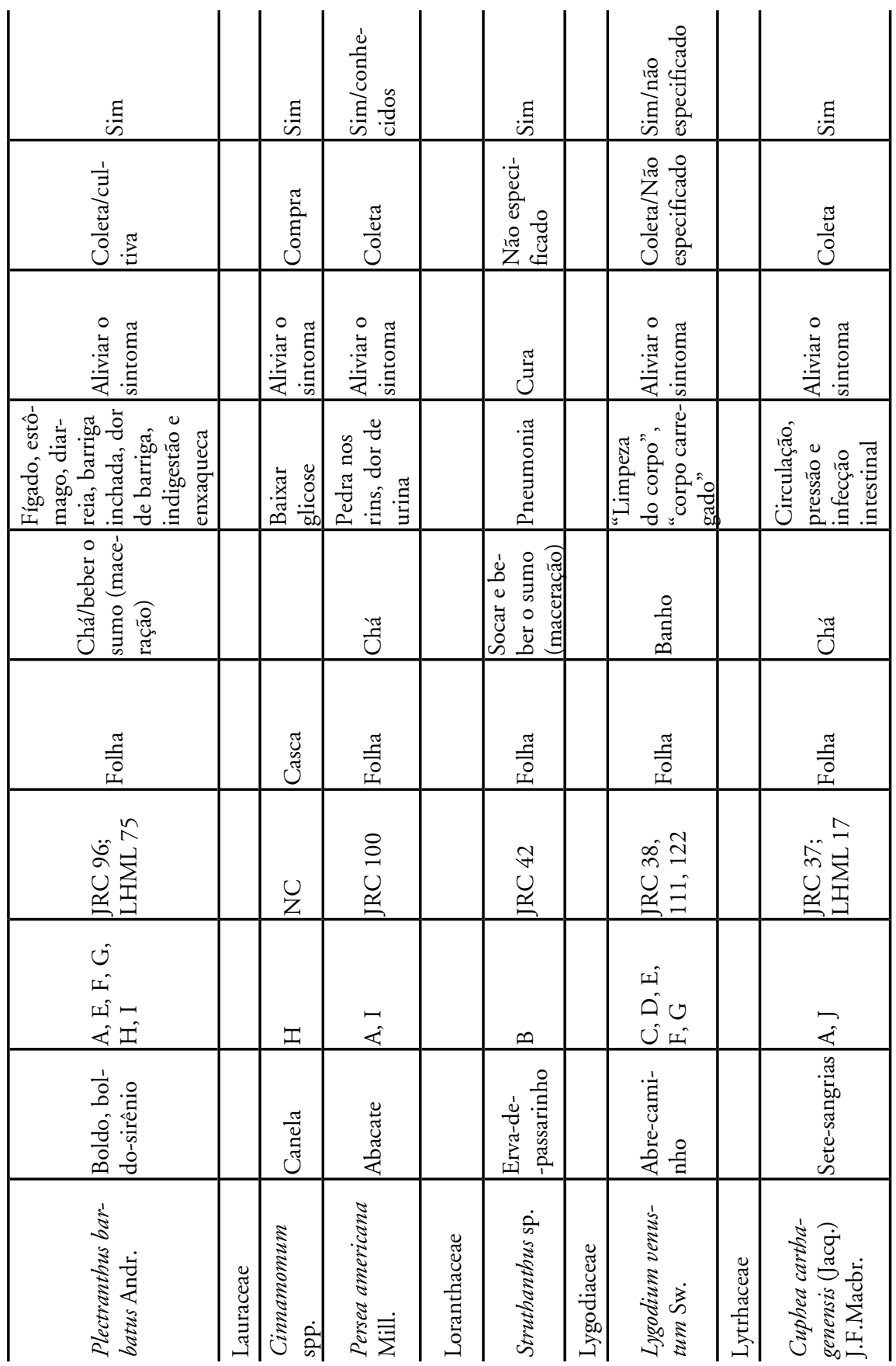


Plantas medicinais:...

111

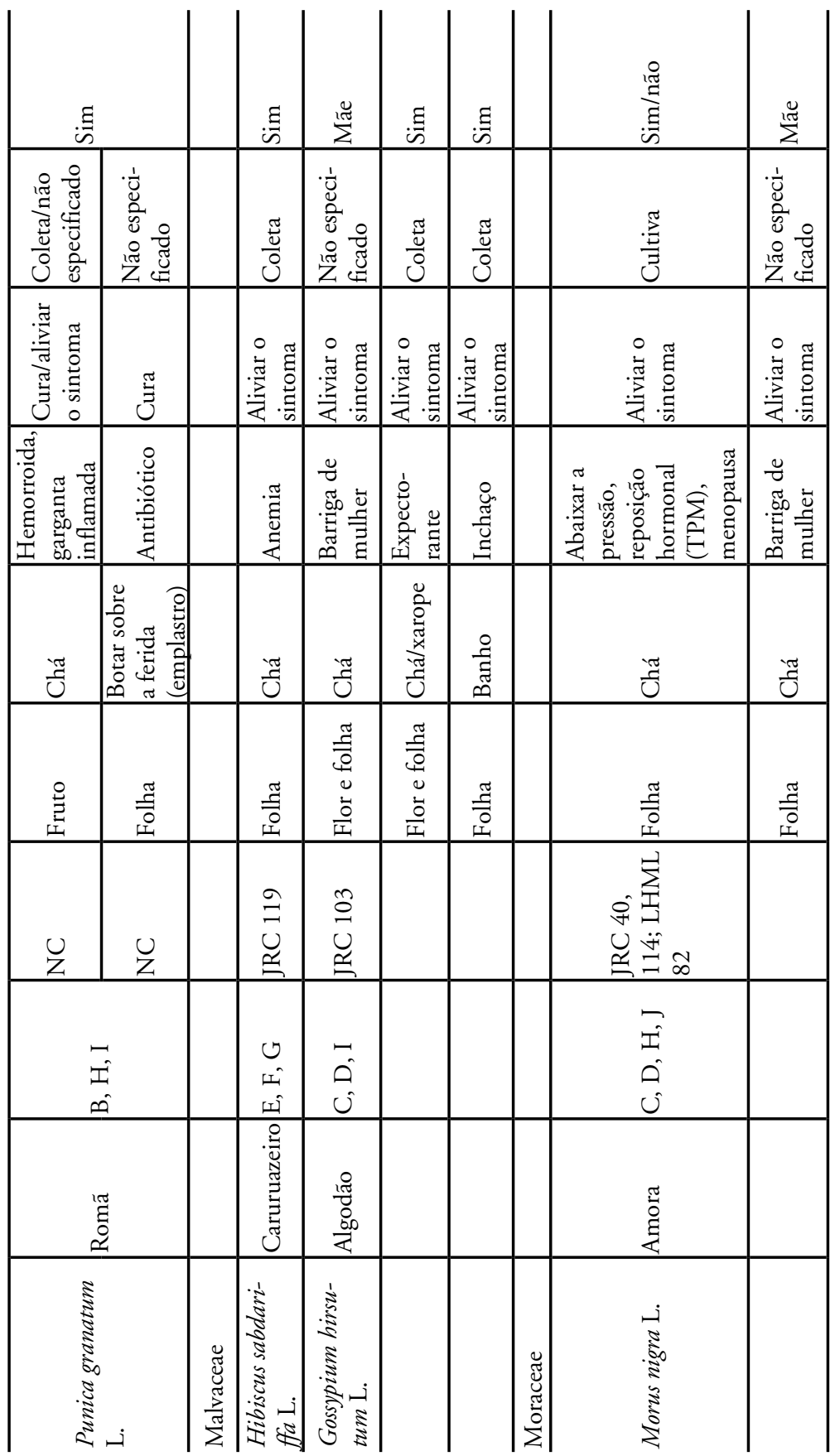


112 O rural em regióes metropolitanas: a Fazenda Engenho Novo, Sáo Gonçalo

\begin{tabular}{|c|c|c|c|c|c|c|c|c|c|}
\hline 烝 & & 豞 & 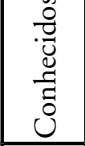 & 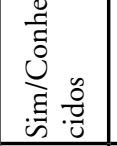 & 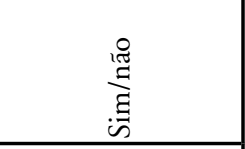 & 㲘 & & 超 & $\sum_{i}^{\pi}$ \\
\hline$\frac{\pi}{0}$ & & $\frac{\tilde{Z}}{\vec{J}}$ & $\stackrel{. \tilde{E}}{\Xi}$ & 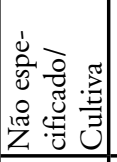 & 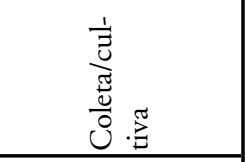 & 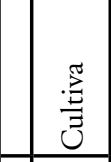 & & 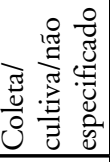 & 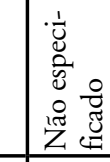 \\
\hline 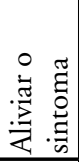 & & 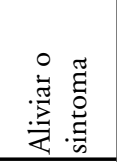 & 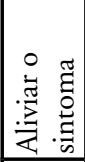 & 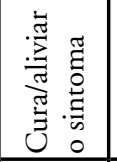 & 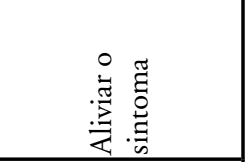 & 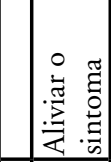 & & 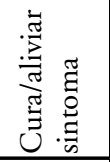 & 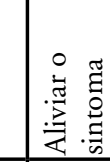 \\
\hline 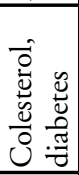 & & 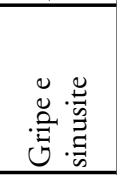 & 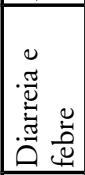 & 㺃 & 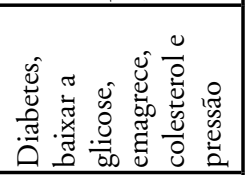 & 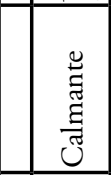 & & 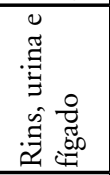 & 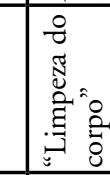 \\
\hline ]ु & & 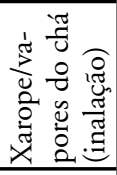 & త్ & 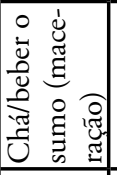 & $\frac{\pi}{3}$ & $\frac{\pi}{0}$ & & 苞 & 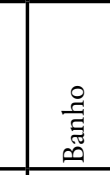 \\
\hline $\begin{array}{l}\stackrel{3}{0} \\
\text { 온 }\end{array}$ & & $\begin{array}{l}\stackrel{3}{0} \\
\frac{0}{0} \\
\end{array}$ & $\begin{array}{l}\stackrel{5}{7} \\
0 \\
\end{array}$ & $\begin{array}{r}\frac{\pi}{0} \\
\frac{0}{0} \\
0 \\
0 \\
0 \\
\end{array}$ & 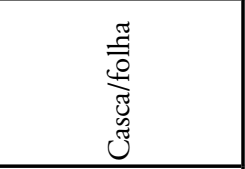 & 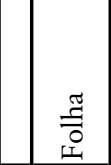 & & $\begin{array}{l}\frac{\pi}{0} \\
0\end{array}$ & $\begin{array}{l}\stackrel{\pi}{0} \\
0\end{array}$ \\
\hline & & U & 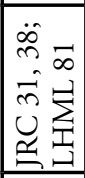 & $\begin{array}{l}n \\
\tilde{n} \\
\approx\end{array}$ & $\begin{array}{l}\infty \\
\Xi \\
\hat{\sigma} \\
0 \\
\cong\end{array}$ & $\begin{array}{l}\stackrel{+}{\infty} \\
\bigcup \\
\cong\end{array}$ & & 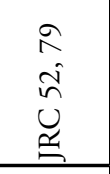 & 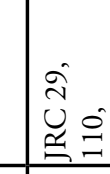 \\
\hline & & $I$ & 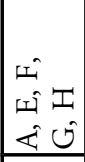 & $\begin{array}{l}I \\
\text { صी }\end{array}$ & $\begin{array}{l}\hat{I} \\
\hat{5} \\
\hat{y} \\
\text { जी }\end{array}$ & $\vec{I}$ & & $\begin{array}{l}\vec{I} \\
\hat{n}\end{array}$ & $\hat{v}$ \\
\hline & & : & 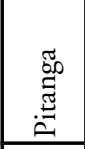 & 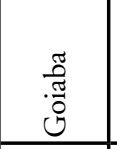 & 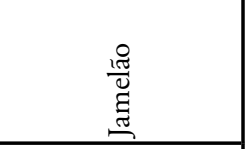 & 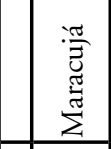 & & 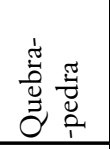 & 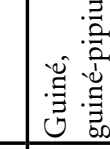 \\
\hline & 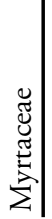 & 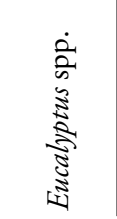 & 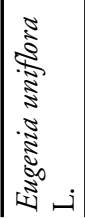 & 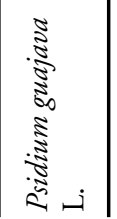 & 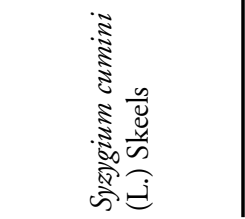 & 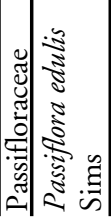 & 窵 & 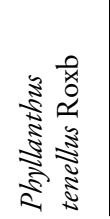 & 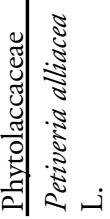 \\
\hline
\end{tabular}


Plantas medicinais:...

113

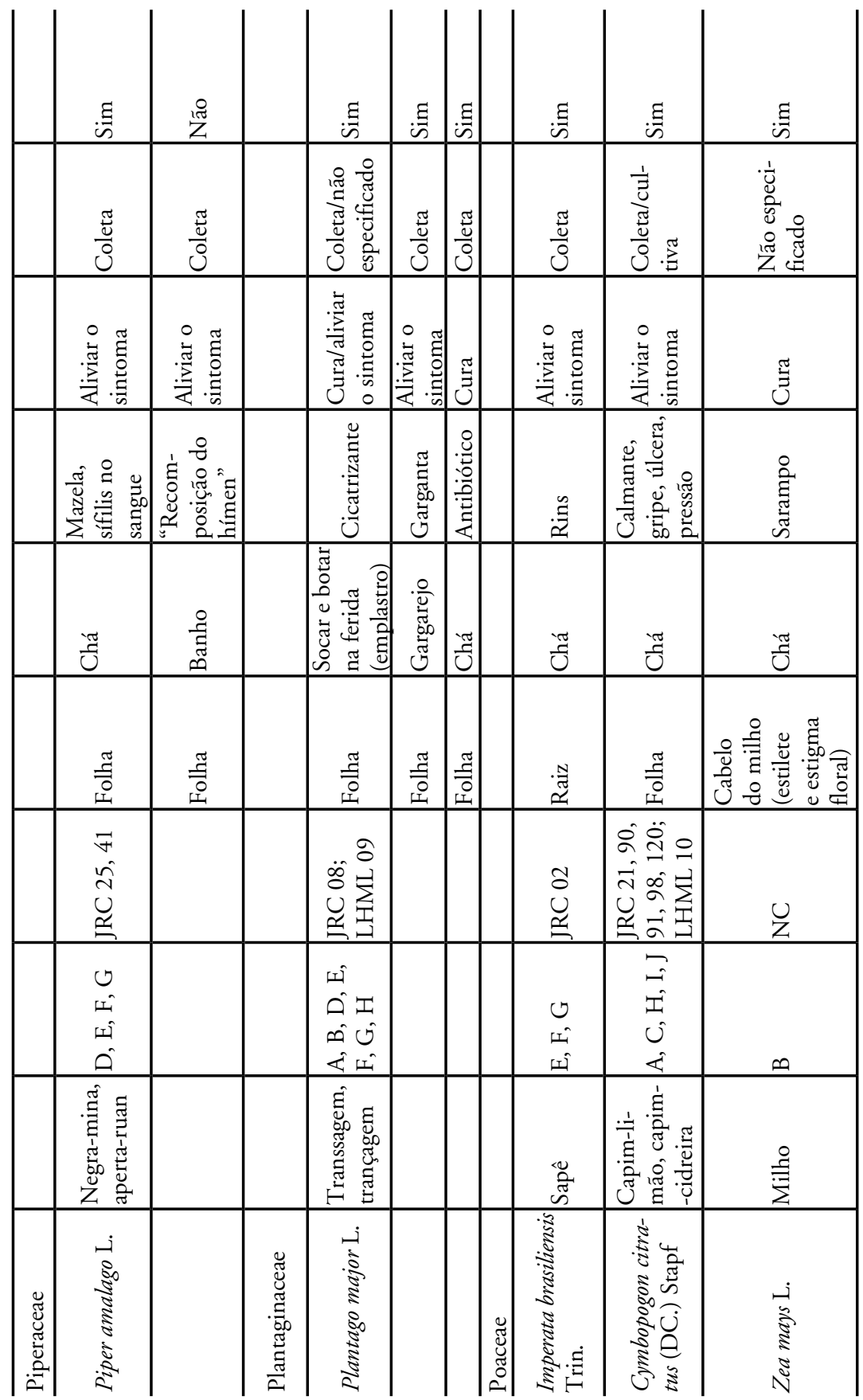


114 O rural em regióes metropolitanas: a Fazenda Engenho Novo, Sáo Gonçalo

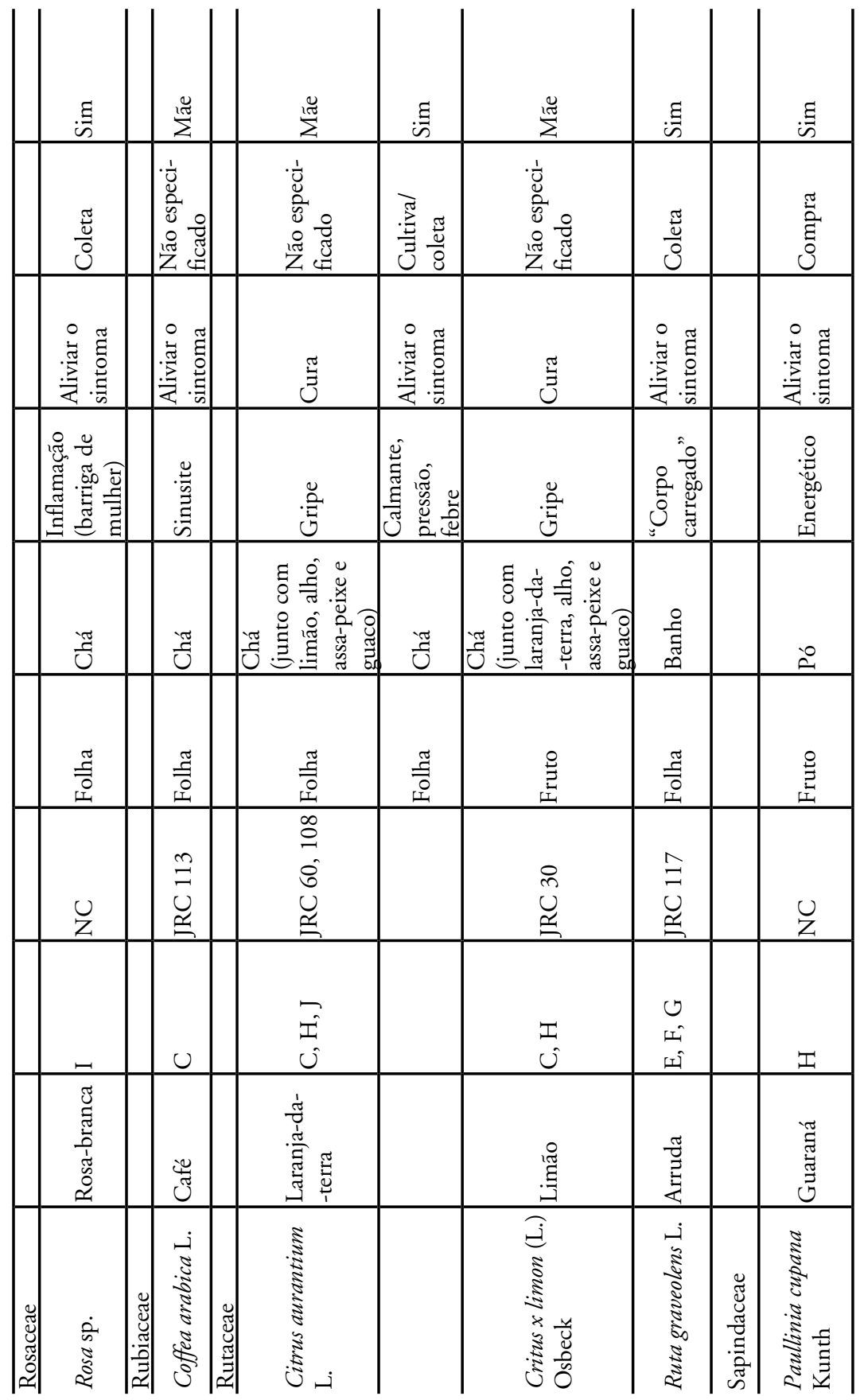


Plantas medicinais:...

115

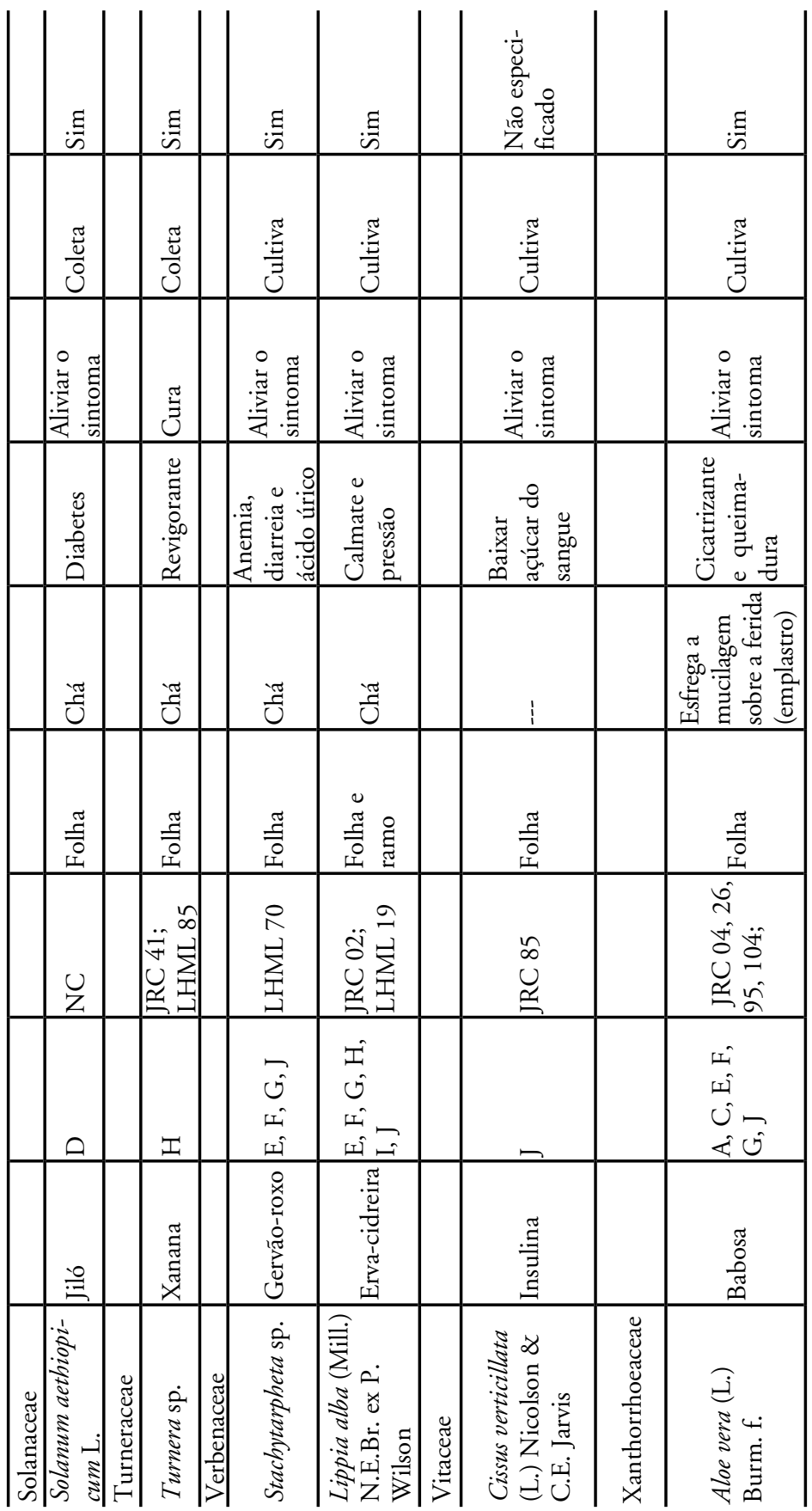


116 O rural em regióes metropolitanas: a Fazenda Engenho Novo, Sáo Gonçalo

\begin{tabular}{|c|c|c|c|c|c|c|c|c|}
\hline$\sum^{\stackrel{\pi}{\pi}}$ & $\sum_{\Sigma}^{\stackrel{\pi}{*}}$ & $\sum^{\stackrel{\pi}{\pi}}$ & है & & 寻 & 寻 & $\begin{array}{l}\stackrel{2}{2} \\
\sum_{\Sigma}^{\pi}\end{array}$ & $\stackrel{\Xi}{n}$ \\
\hline 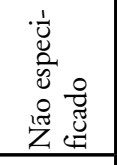 & 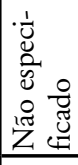 & 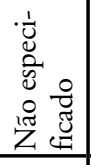 & $\frac{\pi}{0}$ & & 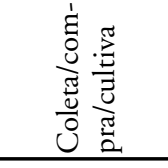 & 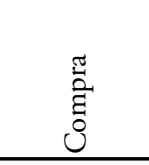 & 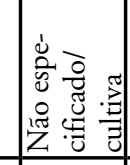 & $\frac{\pi}{0}$ \\
\hline$\widetilde{\Xi}$ & 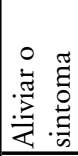 & 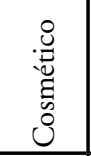 & $\stackrel{\widetilde{\Xi}}{\Xi}$ & & 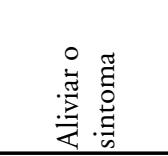 & 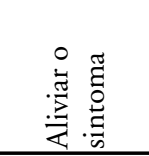 & 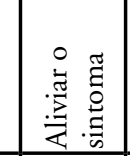 & 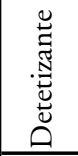 \\
\hline 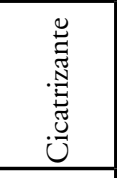 & 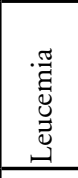 & $\begin{array}{l}\frac{0}{\mathbb{U}} \\
\stackrel{0}{0} \\
\end{array}$ & $\begin{array}{l}0 \\
0 \\
0 \\
0\end{array}$ & & 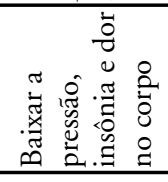 & 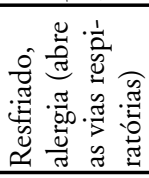 & 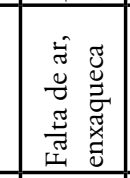 & 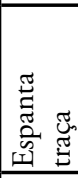 \\
\hline 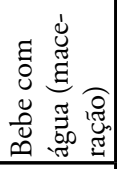 & 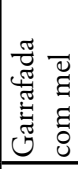 & 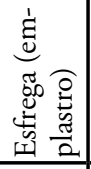 & 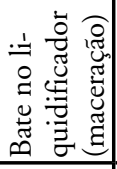 & 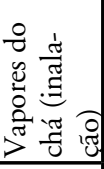 & త్ & 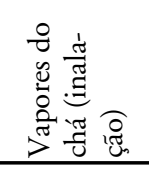 & ]ٓ & 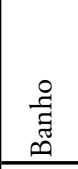 \\
\hline 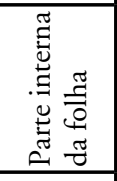 & 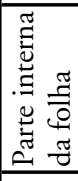 & 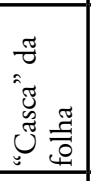 & 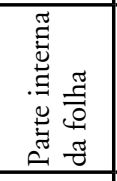 & & $\begin{array}{l}\stackrel{5}{0} \\
\overline{0} \\
\end{array}$ & 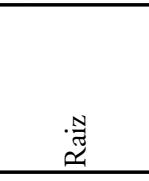 & $\begin{array}{l}\stackrel{5}{0} \\
\text { 足 } \\
\end{array}$ & $\begin{array}{l}\stackrel{\pi}{=} \\
\stackrel{0}{0} \\
\end{array}$ \\
\hline & & & & & 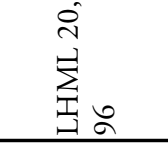 & Z & Z & Z \\
\hline & & & & & $\begin{array}{l}I \\
\hat{U} \\
\tilde{L} \\
\tilde{I}\end{array}$ & $I$ & $\begin{array}{l}I \\
U\end{array}$ & $\begin{array}{l}0 \\
\text { जि } \\
\text { ज्ञ }\end{array}$ \\
\hline & & & & & $\begin{array}{l}\frac{\pi}{3} \\
\frac{0}{0} \\
0 \\
\end{array}$ & 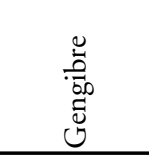 & 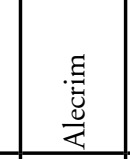 & 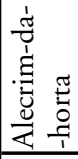 \\
\hline & & & & 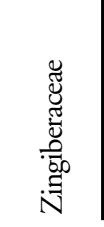 & 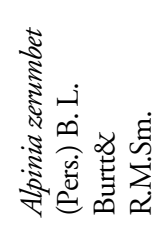 & 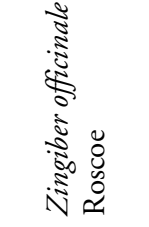 & 离 & \\
\hline
\end{tabular}


Plantas medicinais:...

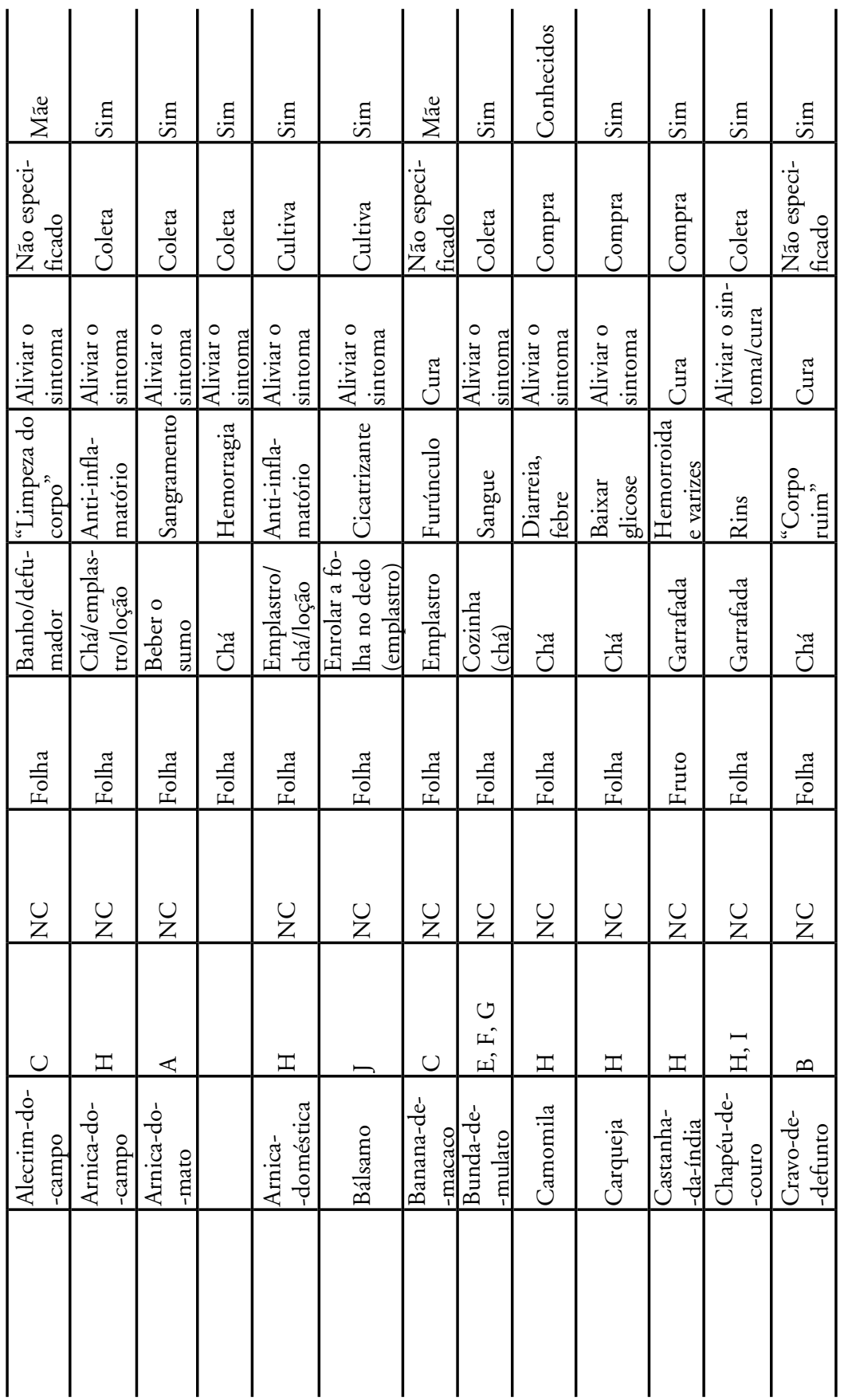


118 O rural em regióes metropolitanas: a Fazenda Engenho Novo, Sáo Gonçalo

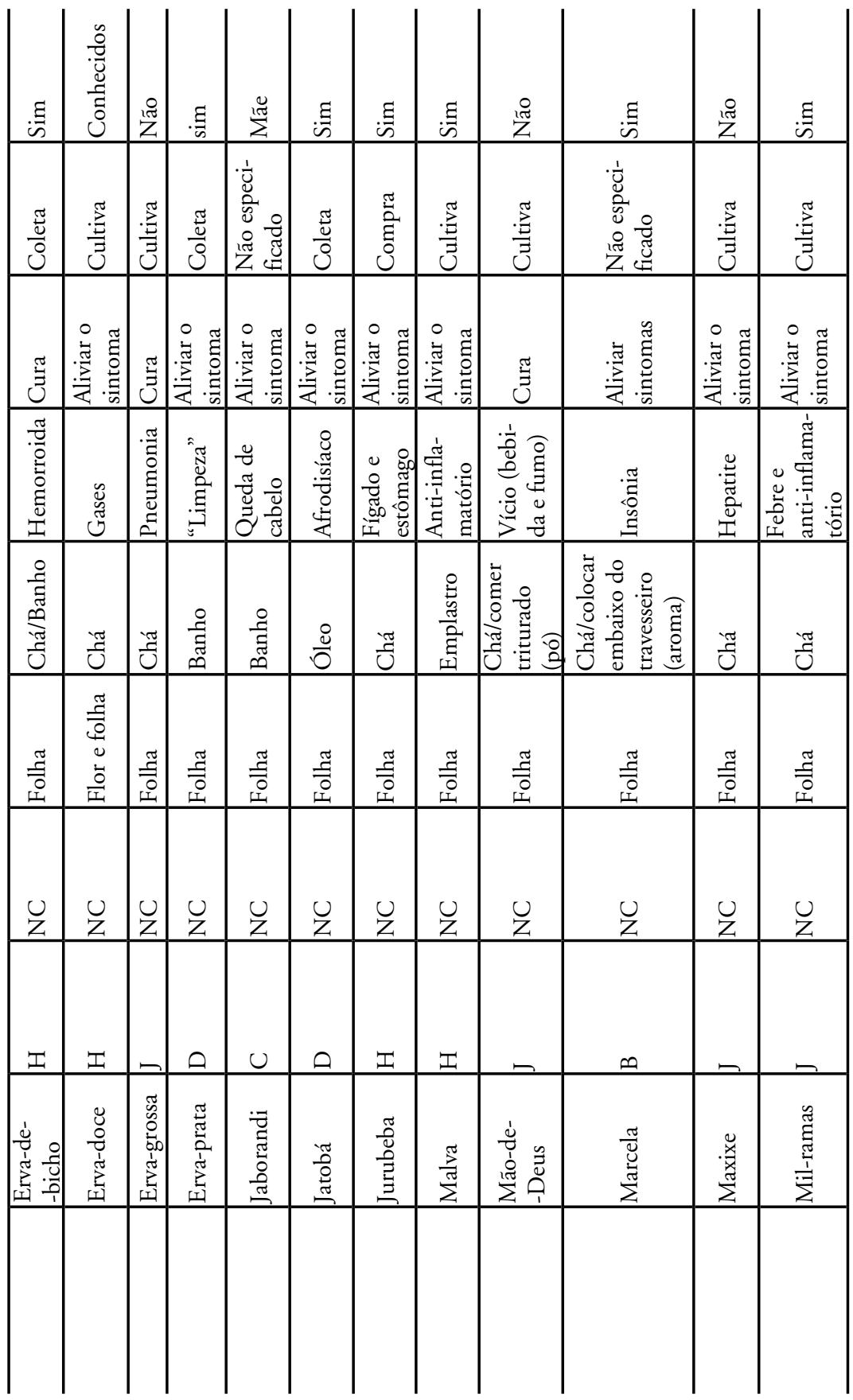


Plantas medicinais:...

119

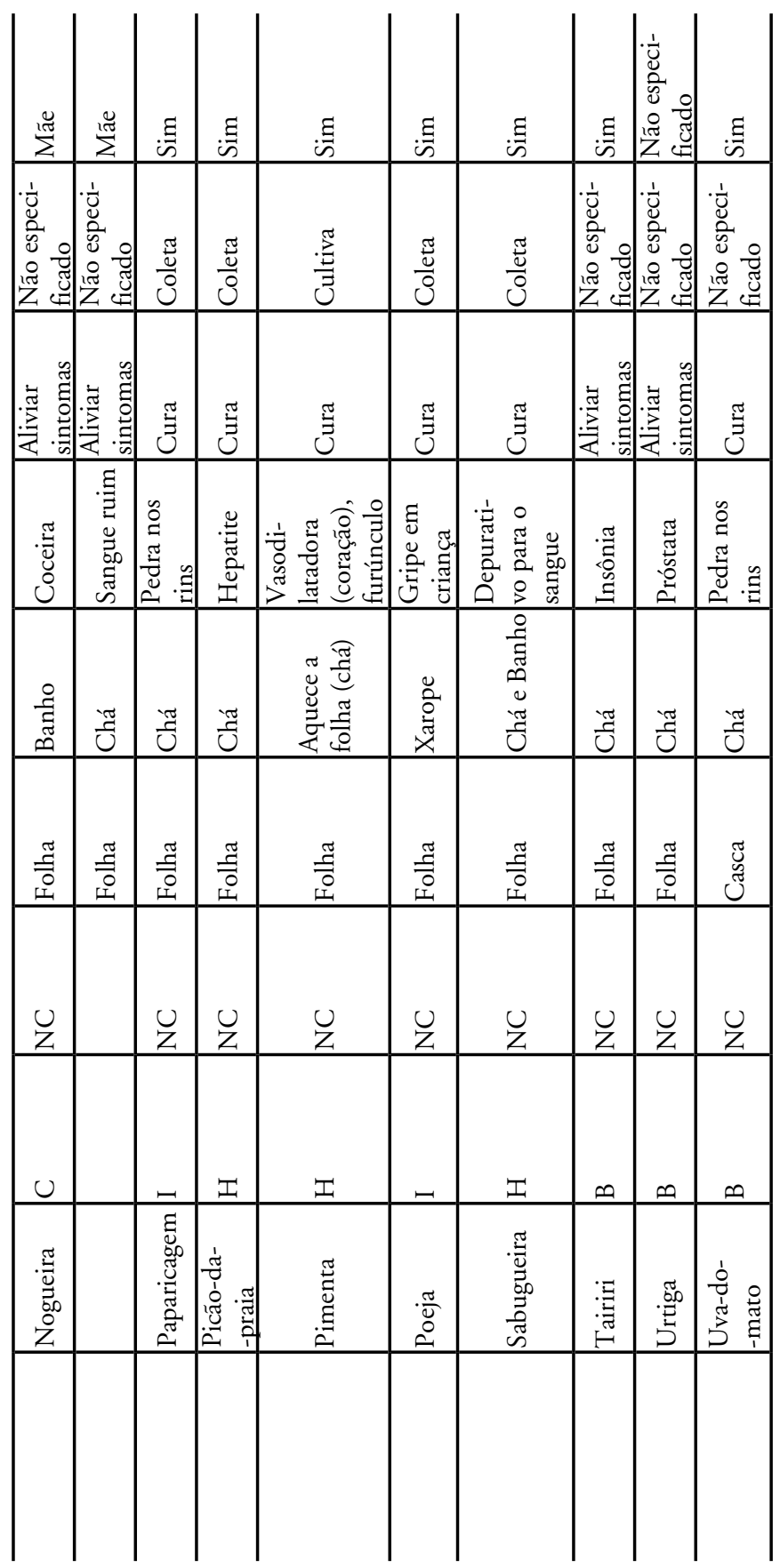

